-ISSN: 2148-0494

dergİabant (AİBÜ İlahiyat Fakültesi Dergisi), Güz 2020, Cilt:8, Sayı:2, 8:613-648

Geliş Tarihi: 06.10.2020 Kabul Tarihi: 24.11.2020

Araștırma Makalesi

Doi: https://doi.org/10.33931/abuifd.806652

\title{
Meslek Yüksekokulu Öğrencilerinin Hadis ve Sünnet Algısı Üzerine \\ Bir Araştırma: Seben İzzet Baysal Meslek Yüksekokulu Örneği
}

\author{
Macit Demirer* \\ Arif Durğun**
}

Öz

$\mathrm{Bu}$ araştırmanın amacı üniversite öğrencilerinin hadis ve sünnet algılarını ve maneviyatlarının hadis ve sünnet alglları üzerindeki etkisini incelemektir. Araștırmada Seben İzzet Baysal Meslek Yüksekokulu'nda eğitim gören 322 öğrenciye ulaşılmıştır. Araştırma için gerekli etik kurul kararları alınarak internet üzerinden öğrencilere anket linki gönderilmiştir. Gönüllülük esasına göre 178 ön lisans öğrencisi ankete katılmıștır. Katılımcıların \%78,1'i kız, \%21,9'u erkektir ve yaș ortalaması 20,47士 1,877'dir. Katılımcıların cinsiyet, yaş, sınıf, bölüm, yaşanılan yer, aile yapısı, ailenin ikamet birimi ve baba eğitim düzeyi değişkenlerine göre hadis ve sünnet algısı ile maneviyat düzeyleri arasında anlamlı bir farklılık bulunmamıștır. Öğrencilerin anne eğitim düzeyi değișkeninde hadis ve sünnet algısı toplam puanı ve bilgi alt boyutunda; öğrencilerin öğrenim gördükleri lise türü değişkeninde hadis ve sünnet algısı bilgi alt boyutunda; dini bilgilerini edinim şekli değisskenine göre hadis ve sünnet algısı biliş alt boyutu ve toplam puanında anlamlı ilișki bulunmuştur. Katılımcıların hadis ve sünnet algısı ile maneviyatları arasında pozitif yönlü $(r=0,461$ $\mathrm{p}=0,000) \% 46,1^{\prime}$ lik korelasyon tespit edilmiştir. Maneviyatın sünnet ve hadis algısı üzerindeki etkisini belirlemek için yapılan regresyon analizinde maneviyatın hadis ve sünnet algısındaki etkisinin 0.117 birim olduğu saptanmıştır. Öğrencilerin Hadis ve sünnet algısı düzeylerinin $(38,59 \pm 7,67)$ ve maneviyat düzeylerinin $(107,09 \pm 14,96)$ yüksek olduğu bulunmuştur. Ayrıca bu çalışmada 10 madde ve iki alt boyuttan oluşan Hadis ve Sünnet Algısı Ölçeği (HSÖ) geliştirilmiştir. Geliştirilen ölçeğin geçerliğini sınamak amacıyla açımlayıcı faktör analizi ve doğrulayıcı faktör analizi yapılmıştır. Ölçeğin toplam varyansın \%63,86'sını açıkladığı ve ardından yapılan doğrulayıcı faktör analizinde ise ölçeğin uyum endekslerini karşıladığı sonucuna ulaşılmıştır.

Anahtar Kelimeler: Hadis, Sünnet, Maneviyat, Hadis ve Sünnet Algısı, Üniversite Öğrencileri.

Dr. Öğr. Üyesi, Bolu Abant İzzet Baysal Üniversitesi İlahiyat Fakültesi, Temel İslam Bilimleri Bölümü, Hadis Anabilim Dalı, macitdemirer@ibu.edu.tr

ORCID ID 0000-0002-3192-0323

** Ö̈̆gr. Gör., Bolu Abant İzzet Baysal Üniversitesi Seben İzzet Baysal Meslek Yüksekokulu, Sosyal Hizmet ve Danışmanlık Bölümü, Sosyal Hizmetler Programı, arifdurgun@ibu.edu.tr ORCID ID 0000-0001-8210-7343 


\title{
A study on Vocational High School Students' Perception of Hadith and Sunnah: Seben İzzet Baysal Vocational High School Case
}

\begin{abstract}
The aim of this study is to examine university students' perceptions of hadith and sunnah and the effect of their spirituality on perceptions of hadith and sunnah. 322 students studying at Seben İzzet Baysal Vocational School were reached in the research. The necessary ethical committee decisions for the research were made and a questionnaire link was sent to the students online. 178 associate degree students participated in the survey on a voluntary basis. $78.1 \%$ of the participants are girls and $21.9 \%$ are boys, and the average age is $20.47 \pm 1.877$. No significant difference was found between the perception of hadith and sunnah and spirituality levels according to the variables of gender, age, class, department, place of residence, family structure, family's residence unit and father's education level. Hadith and sunnah perception in the mother education level variable of the students in the total score and knowledge sub-dimension; Hadith and sunnah perception in the knowledge sub-dimension of the high school type variable that students attend; A significant relationship was found in the perception of hadith and sunnah cognition sub-dimension and total score according to the variable of acquiring religious knowledge. A positive correlation of $46.1 \%(r=0.461 \mathrm{p}=0.000)$ was found between the participants' perception of hadith and sunnah and their spirituality. In the regression analysis performed to determine the effect of spirituality on the perception of sunnah and hadith, it was found that the effect of spirituality on the perception of hadith and circumcision was 0.117 units. It was found that the students' perception of hadith and sunnah (38.59 \pm 7.67$)$ and their spirituality level $(107.09 \pm 14.96)$ were high. In addition, the Perception of Hadith and Sunnah Scale (HSS), consisting of 10 items and two sub-dimensions, was developed in this study. Exploratory factor analysis and confirmatory factor analysis were conducted to test the validity of the developed scale. It was concluded that the scale explained $63.86 \%$ of the total variance and in the confirmatory factor analysis performed afterwards, the scale met the fit indexes.
\end{abstract}

Keywords: Hadith, Sunnah, Sprituality, Perception of Hadith and Sunnah, Undergraduate Students.

\section{Giriş}

Sünnet ve hadis kavramları günümüzde gerek Temel İslam Bilimleri açısından gerekse de Felsefe ve Din Bilimleri açısından çeşitli araştırmalara konu olmaktadır. Literatürdeki araştırmalara dikkat edildiğinde hadis ve sünnete ilişkin çalışmalar ekseriyetle toplumsal dinamiklere bakan yönünden ziyade hadis ve sünnetin ravileri ve sahihliği ekseninde yoğunlaşmıștır. ${ }^{1}$ Oysaki hadis ve sünnet toplumsal gerçekliklerden ve toplumsal düzeni sağlama fonksiyonundan bağımsız olarak nitelendirilmesi düşünülemez. ${ }^{2}$ Özellikle günümüz postmodern, bireyci ve çözülmeye yüz tutmuş toplum yapısı içerisinde manevi dinamiklerimizden biri olan hadis ve sünnet kavramlarına bugün eskiden daha çok muhtaç olduğumuzu söylemek yanlış olmayacaktır.

1 Mustafa Tekin, “Sünnet ve Toplumsal Dinamikler”, İlahiyat Akademi Dergisi 7-8 (Aralık 2018), 163.

2 Ahmed Ürkmez, “Sosyal Kesimler ve Sünnet Algıları Araştırması: Malatya (Hadis Alan Yorumu)", Süleyman Demirel Üniversitesi İlahiyat Fakültesi Dergisi 28 (Haziran 2012), 98. 
Literatürde sünnet ve hadise ilişkin birçok tanıma rastlamak mümkündür. Fakat burada hadis ve sünnet kavramlarının tanımlanması noktasında bir tekerrüre mahal vermeden konunun psikososyal ve toplumsal bağlamda anlaşllabilmesi ve bağlantılandırılması açısından mezkûr kavramların sosyal yönüne bakan bazı içeriklerine yer vermemiz, konunun anlaşılması açısından önem arz etmektedir.

Sünnet, İslam literatürünün temel dinamiklerinden biri olarak $\mathrm{Hz}$. Peygamber'in fiilleri şeklinde tanımlamak mümkündür. Bununla birlikte sünnet bir bakıma Allah'ın Kur'an-ı Kerim'inde gönderdiği emirlerinin ve marziyatının $\mathrm{Hz}$. Peygamber'in ahvalinde ve etvarında tecessüm etmiş şeklidir. Dolayısıyla İslam dininin müntesipleri tarih boyunca Allah'ın rızasını elde etmenin en önemli yollarından biri olarak Hz. Peygamber'in sünnetine ittiba etmeyi önemli görmüşlerdir. Elbette sünnetin Allah'ın rızasına nail olma gibi oldukça önemli bir fonksiyonu olması yanında toplumsal hayata yön veren adaleti, vicdanı, merhameti, insan hakları, değeri ve onurunu gözetmeyi, insanın gerek bireysel gerekse de toplumsal yaşamını hem dünyada hem de ahirette mamur eden yönü yadsınamaz. Hadis ise Hz. Peygamber'in efalinden ziyade akvali anlamında anlaşılabilir. Her ne kadar Hz. Peygamberin sözlerini ifade etmiş olsa da hadis de sünnetin bir parçası olarak değerlendirilebilir. Bununla birlikte hadis kelimesi ve çoğulu olan ehadis kelimesi "gelenekler/adetler" şeklinde de tesmiye edilmiştir. ${ }^{3}$

Sünnetin iki boyutundan bahsetmek mümkündür. Biri uhrevi boyut diğeri ise dünyevi boyuttur. Toplumsal bağlamda sünnet kavramına baktığımızda elbette dünyevi ciheti akla gelmektedir. Bu bağlamda sünnet temel sosyolojik kurumlar gibi faaliyet gösterebilmekte, hem bir paradigma hem de bir pratik olarak nesilden nesile aktarılmakta, toplumsal normları, ilişkileri belirlemekte ve topluma bir bakış açısı kazandırarak, toplumun geleceğinin inşasında belirleyici bir rol oynayabilmektedir. ${ }^{4}$ Müslüman bir birey sünnet vasitasıyla Hz. Peygamber'in nasıl davrandığı, insan ilişkilerinde ve toplumsal yaşamda nasıl hareket ettiğini, neleri sevdiğini, neleri yediğini ve içtiğini, nelerden kaçındığını ve nasıl ibadet ettiğini vb. görür ve hayatına tatbik etmeye çalışır. ${ }^{5}$

Tarihsel süreçte sünnet pratikleri nesilden nesile aktarılırken sünnet-toplum perspektifinde birtakım kırılmalar yaşanmıștır. Sünnet olmayan fakat sünnetmiş gibi kabul edilen birtakım uygulamalar sünnete eklenmiş ve bunlar zamanla sahih sünnet olarak anlaşılmaya başlanmıştır. ${ }^{6}$ Burada hadis ve sünneti nesilden nesile aktaran bir kısım kimselerin kendi tasavvurları ve kurgularını dahil etmesi ve/ya doğru

Seyyed Hossain Nasr, "Sunnah and Hadith", çev. İbrahim Hatipoğlu, Hadis Tetkikleri Dergisi 4/1 (Haziran 2006), 119.

Tekin, "Sünnet ve Toplumsal Dinamikler", 170.

Nasr, "Sunnah and Hadith", 119.

Ürkmez, "Sosyal Kesimler ve Sünnet Algıları Araştırması: Malatya (Hadis Alan Yorumu)”, 99. 
kaynaktan referans almamasının sonucunda kitlelerin hadis ve sünnet algısında kırılmalara olagelmiştir. ${ }^{7}$

Maneviyat kavramı, toplumsal zihnimizde genellikle din ve ahlak kavramlarıyla ilişkilendirilse de batı literatüründe kapsam daha geniş tutulmakta ve din dışı, inanç, düşünce ve duyguları da kapsayan bir kavramsallaştırmayı ihtiva etmektedir. $^{8}$ Literatürde maneviyat kavramı iki yaklaşım ekseninde değerlendirilmektedir. Bunlardan birincisi toplumsal zihnimizde canlandırdığ yönüyle ele alan yaklaşım ki maneviyatı belirli bir dine intisap ve o dinin gereklerini ifa etme şeklinde ele almakta ve nihayetinde dindarlığ netice vermektedir. ${ }^{9} \mathrm{Bu}$ hususta Jung dinin ve maneviyatın insanın psişesinin önemli bir argümanı olduğunu, bireyin psikolojik bütünlügünü sağlamada önemli bir rol oynadığını ifade ederken aynı zamanda bir adım daha ileri giderek din ve manevi boyutu eksik bir psikolojik yaklaşımın kusurlu olabileceğini ifade etmektedir. ${ }^{10}$ Diğer yaklaşım ise maneviyata psikoloji disiplini ekseninde bakmakta ve insan doğasındaki güce vurgu yapmaktadır. ${ }^{11} \mathrm{Bu}$ bakımdan maneviyata din ve inanç kavramlarını içeren, yaşamda bir anlam arayan, kendisinden üstün bir güce inanma ve bağlanmayı içeren, dinle ilişkili olabileceği gibi din dışı kavramlarla yaşanabilen, hümanistlik bakış açılarını barındıran ve insan doğasındaki güçleri ön plana çıkartan deneyimler şeklinde bakmak yanlış olmayacaktır. ${ }^{12}$

Maneviyatın dini inancı içeren yaklaşımından hareketle hadis ve sünnet kavramları ile maneviyat arasında pozitif yönlü doğrusal bir ilişki olacağı düşünülmüştür. Dolayısıyla bu araştırmamızda üniversite öğrencilerinin hadis ve sünnet algılarının ne olduğunun belirlenmesi amaçlanmış ve bunun öğrencilerin maneviyatlarıyla nasıl bir ilgileşim gösterdiği merak konusu olmuştur. Nitekim Hadis alanındaki literatür incelendiğinde araştırmamızın konusu ve kapsamına yönelik niceliksel araştırma metoduyla yeterince bilimsel çalışmanın yapılmadı̆̆ görülmüştür. Bu da araştırmamızın önemini daha da artırmaktadır. Bu çalışmamızla ilgili olarak öncelikle bireylerin hadis ve sünnet algısını ölçecek standart bir ölçeğin olup olmadığı araştırılmış fakat hadis ve sünnet algısını ölçecek bir ölçeğe rastlanmamıştır. Bu sebepten öncelikle ölçek geliştirmeye benzer bir metod izlenmiş ve öğrencilerin hadis ve sünnet algısını ölçmeye yönelik likert tipi 10 maddeden oluşan standart bir ölçek de bu çalışmamızda geliştirilmiştir. Akabinde Turgay Şirin tarafından geliştirilen Maneviyat Ölçeği araştırmamızda kullanılmış olup maneviyatın

7 Mahmut Yeşil, “Va'z Edebiyatında Hadisler” (Ankara: TDV Yayınları, 2001), 173-250 akt. Ahmed Ürkmez, “Sosyal Kesimler ve Sünnet Algıları Araştırması: Malatya (Hadis Alan Yorumu)”, 99.

8 Arslan Karagül, "Manevi Bakım: Anlamı, Önemi, Yöntemi ve Eğitimi (Hollanda Örneği)", Dini Araştırmalar 14/40 (Haziran 2012), 8.

$9 \quad$ Joanne Colye, "Spirituality and Health: Towards a Framework for Exploring the Relationship Betwen Spirituality and Health", Journal of Advanced Nursing 37/6 (March 2002), 589-597.

10 Carl Gustav Jung, Psikoloji ve Din, çev. Raziye Karabey (İstanbul: Okyanus Yayınevi, 2010), 10-96.

11 Yusuf Genç-Arif Durğun, "Manevi Bakımın Gerekliliği ve Bakım Hizmeti Veren Meslek Elemanlarının Manevi Bakıma İlişkin Düşünceleri", Turkish Studies Comperative Religious Studies 13/9 (Spring 2018), 51.

12 Turgay Şirin, "Maneviyat Ölçeği'nin Geliştirilmesi: Geçerlik ve Güvenirlik Çalıșması”,Turkish Studies Social Sciences 13/18 (Summer 2018), 1289. 
hadis ve sünnet algısına etkisinin olup olmadığına istatistiksel teknikler kullanılarak bakılmıştır.

\section{Yöntem}

\subsection{Araştırmanın Amacı, Önemi, Problemi ve Hipotezleri}

Bu çalışma meslek yüksekokulu öğrencilerinin Hz. Muhammed'in (s.a.v) din ve dünya görüşü olan hadis ve sünnet kavramlarına ilişkin algı düzeylerinin belirlenmesini konu edinmektedir. Bu çalışmada toplumda önemli mevkilere namzet ve geleceğe yön verecek üniversite öğrencilerinin hadis ve sünnet algılarının ne olduğunun belirlenmesi ile hadis ve sünnet hakkında gerek camilerde gerek kitle iletişim araçlarında gerekse de okullarda din dersleri aracılığıyla verilen eğitimin düzeyinin tespiti amaçlanmaktadır. Ayrıca hadis ve sünnet algısı ile maneviyat arasında herhangi bir korelasyonun olup olmadığının istatistiksel olarak saptanması da hedeflenmektedir. Literatür incelendiğinde ilahiyat alanında araştırma konumuzla ilgili yeterince çalışma yapılmadığı anlaşılmıştır. Bu açıdan bakıldığında niceliksel araştırma bağlamında literatüre kaynak teşkil edeceği değerlendirilmektedir.

Bu konunun ele alınmasında, bireyin hayatında sünnet ve hadisin etkisinin ne olduğu, özellikle Türk toplumunun geleceğine yön verecek olan üniversite gençliğimizin maneviyatını oluşturan unsurlardan biri olarak değerlendirebileceğimiz hadis ve sünnet kavramlarına ilişkin algı düzeylerinin belirlenmesi, ilahiyat alanında çalışan akademisyenlere ve ilgililere kaynak teşkil edeceği gerçeği çalışmanın önemini oluşturmaktadır.

Araştırmanın sorusu ve hipotezleri şöyledir:

Araştırmada meslek yüksekokulu öğrencilerinin hadis ve sünnet algısının ne olduğu hedeflenerek;

1. Meslek yüksekokulu öğrencilerinin sünnet ve hadis kavramları hakkında nasıl bir algıya sahip oldukları,

2. Sünnet ve hadis kavramlarına ilişkin algı düzeylerinin kendi maneviyatlarıyla bir farklılık gösterip göstermediği sorularına cevap aranmaya çalışılmıştır.

Bu bağlamda hipotezlerimiz şöyledir: ilișki vardır.

H-1: Öğrencilerin cinsiyetleri ile sünnet ve hadis algısı arasında anlamlı bir

H-2: Öğrencilerin yaşları ile sünnet ve hadis algısı arasında anlamlı bir ilişki vardır.

H-3: Öğrencilerin okudukları bölümler ile sünnet ve hadis algısı arasında anlamlı bir ilişki vardır. 
H-4: Öğrencilerin okudukları sınıf ile sünnet ve hadis algısı arasında anlamlı bir ilişki vardır.

H-5: Öğrencilerin ikamet ettikleri yer ile sünnet ve hadis algısı arasında anlamlı bir ilişki vardır.

H-6: Öğrencilerin annelerinin eğitim durumu ile sünnet ve hadis algısı arasında anlamlı bir ilişki vardır.

H-7: Öğrencilerin babalarının eğitim durumu ile sünnet ve hadis algısı arasında anlamlı bir ilişki vardır.

H-8: Öğrencilerin aile yapıları ile sünnet ve hadis algısı arasında anlamlı bir ilişki vardır.

H-9: Öğrencilerin ailelerinin ikamet ettikleri yer ile sünnet ve hadis algısı arasında anlamlı bir ilişki vardır.

H-10: Öğrencilerin öğrenim görmüş oldukları lise türü ile sünnet ve hadis algısı arasında anlamlı bir ilişki vardır.

H-11: Öğrencilerin dini bilgilerini aldıkları kaynaklar ile sünnet ve hadis algısı arasında anlamlı bir ilişki vardır.

H-12: Öğrencilerin maneviyatları ile sünnet ve hadis algısı arasında anlamlı bir ilişki vardır.

\subsection{Evren ve Örneklem}

Araştırmanın evrenini Bolu İli Seben İlçesinde faaliyet gösteren Bolu Abant İzzet Baysal Üniversitesine bağlı olarak faaliyet gösteren Seben İzzet Baysal Meslek Yüksekokulu'nda öğrenim gören öğrencilerini kapsamaktadır. Araştırmanın örneklemini kitlesini ise Seben İzzet Baysal Meslek Yüksekokulu'ndaki çeşitli bölümlerde öğrenim gören 176 ön lisans öğrencisi oluşturmaktadır. Örneklem seçiminde tesadüfi örneklem tercih edilmiştir.

\subsection{Veri Toplama Araçları}

Bir araştırmada, araştırmanın konusuna, niceliğine ve niteliğine uygun veri toplama araçları tercih edilir. Özellikle büyük kitlelerle yapılan araştırmalarda anket tekniği çoğunlukla tercih edilmektedir. Bu araştırmada da bu niteliğe uygun olarak büyük kitlelere uygulanması en elverişli veri toplama aracı olan anket tekniği tercih edilmiştir. Anketler COVID-19 pandemisi nedeniyle daha önceden hedeflendiği şekilde yüz yüze gerçekleştirilememiştir. Bu sebepten anket online platformlar üzerinden araştırmanın evrenini oluşturan yaklaşı 322 ön lisans öğrencisine link gönderilmek suretiyle gerçekleştirilebilmiştir. Anket içeriği iki kısma ayrılarak öncelikle demografik bilgilerin bulunduğu kısım oluşturulmuş sonraki kısımda ise araştırmamızın amacına hizmet edecek ölçeklere yer verilmiştir. Katılımcıların demografik bilgilerini öğrenmek için yaş, cinsiyet, öğrenim görülen bölüm ve sınıf, 
kalınan yer, ebeveynlerin eğitim durumu ve iș durumu, ekonomik düzeyi, aile yapısı ve ailelerinin ikamet durumları, öğrenim görülen lise türü, lisede Din Kültürü ve Ahlak Bilgisi dersi alma durumu, dini bilgilerinin en çok hangi kaynaktan elde edildiği ile hadis ve sünnet hakkında bilgi düzeylerine dair 17 soruya yer verilmiștir. Bunun yanında araştırmamızın hipotezlerine uygun olarak; Ahmed Ürkmez tarafından yapılan araştırmadan da yararlanarak araştırmacılar tarafından 5'li likert tarzında 10 sorudan ve iki alt boyuttan oluşan, hadis ve sünnet algısını ölçmeye yönelik bir ölçek geliştirilmiştir. Bu araştırmada hazırlanan 5'li likert tarzı ölçeğe "Hadis ve Sünnet Algısı Ölçeği" (HSÖ) ismi verilmiştir olup geçerlilik ve güvenilirlik çalışması yapılmıştır. Kullanılan bir diğer ölçek ise Turgay Şirin tarafından geliştirilen Maneviyat ölçeğidir.

\subsection{Hadis ve Sünnet Algısı Ölçeği}

Hadis ve Sünnet Algısı Ölçeği (HSÖ) 5'li likert tipi bir ölçek olup tamamı olumlu 10 maddeden oluşmaktadır. Ölçek maddeleri 1- Kesinlikle katılmıyorumdan 5- kesinlikle katılıyoruma doğru gitmektedir. Ölçeğin iki alt boyutu vardır. Bunlardan birincisi "duygu ve davranış boyutu" ikincisi de "bilgi boyutu"dur. Ölçekten alınabilecek en düşük puan 10 en yüksek puan ise 50'dir. Puan yükseldikçe hadis ve sünnet algısı düzeyi de yükselmektedir. Ölçeğin standart bir puanlaması olmamakla birlikte 10 (düşük) < 23-36 (Orta) < 37 (Yüksek) şeklinde kategorize edilerek değerlendirilebilir.

\subsection{Maneviyat Ölçeği}

Maneviyat Ölçeği, 5’li likert tipi bir ölçek olup 3 olumsuz 24 olumlu toplam 27 maddeden oluşmaktadır. Ölçek maddeleri "(1) Bana Hiç Uygun Değil, (2) Bana Uygun Değil, (3) Bana Biraz Uygun, (4) Bana Oldukça Uygun, (5) Bana Tamamen Uygun" şeklinde 5'li likert tarzında hazırlanmış olup, ölçekte yer alan olumsuz maddeler değerlendirmeye alınmadan önce ters kodlanmaktadır. Ölçek toplam puanı açısından değerlendirildiğinde ölçekten alınacak en yüksek puan 135, en düşük puan ise 27'dir. Ölçeğin her bir alt boyutundan alınan yüksek puan bireyin ilgili alt boyutun değerlendirdiği özelliğe sahip olduğunu göstermektedir. Ölçek ayrıca toplam maneviyat puanı vermektedir. Ölçekten alınan yüksek puan, kişide maneviyatın yüksek düzeyde olduğunu göstermektedir. ${ }^{13} \mathrm{Bu}$ çalışmada ölçek, toplam maneviyat puanı üzerinden değerlendirilmiştir.

\subsection{Verilerin Analizi}

Veriler IBM SPSS 22 programına aktarlarak frekans, yüzdelik dilimler, aritmetik ortalamaları, standart sapmaları hesaplanmıştır. "Hadis ve Sünnet Algısı Ölçeği”nin yapı geçerliliğini tespit etmek amacıyla açıklayıcı (açımlayıcı) faktör analizi ve doğrulayıcı faktör analizi yapılmıștır. Doğrulayıcı faktör analizi AMOS 23 programı ile gerçekleştirilmiştir. Maneviyat ölçeğiyle ilgili yapı geçerliliği çalışması

13 Şirin, “Maneviyat Ölçeği'nin Geliștirilmesi: Geçerlik ve Güvenirlik Çalıșması”, 1304. 
tekrardan yapılmamıș olup sadece Cronbach alpha değerlerine bakılmış ve ölçeğin toplam puanı üzerinden ileri istatistik çalışmaları yapılmıştır. Hipotezlerimizi test etmek için hangi ilişki testlerinin yapılmasına karar verilirken öncelikle varyansların normal dağılım varsayımını karşılayıp karşılamadığına bakılması gerekmektedir.

Yapılan normallik testi neticesinde gerek HSÖ ölçeği ve alt boyutlarında gerekse de Maneviyat Ölçeği'nde normallik varsayımı karşılanmadığından nonparametrik testler kullanılmamıştır. Bu doğrultuda iki grup arasındaki farkın anlamlı olup olmadığını araştırırken Mann Whitney U testinden, üç ve daha fazla olan grupların arasındaki fark araştırılırken de Kruskal Wallis $\mathrm{H}$ testinden faydalanılmıştır. Ayrıca Spearman korelasyon analizi de yapılmış olup değişkenler arasındaki ilişkiler ölçülmüştür.

\section{Bulgular ve Yorum}

\section{1. Ölçeklerin Yapı Geçerliliği ve Güvenilirliği}

Hadis ve Sünnet Algısı Ölçeği (HSÖ) standart bir ölçek olmayıp bu çalışmada standardize edilmiştir. Öncelikle belirtmek gerekir ki bu çalışma bir ölçek geliştirme çalışması değildir. Fakat oluşturulan maddelerin 5'li likert tarzında ve 20 maddeden oluşması neticesinde ölçek geliştirmeye benzer metot izlenmiştir. Öncelikle ölçeğin Cronbach Alfa güvenilirlik katsayısına bakılmıştır. Bununla birlikte madde-toplam korelasyonu ile iç tutarlılı̆̆ tespit edilmiştir. Madde-toplam korelasyonu yüksek olması beklenmektedir. Zira maddeler arasındaki korelasyonun yüksek olması benzer davranışların ölçüldüğünü ve iç tutarlılığının yüksek olduğunu göstermektedir. Madde-toplam korelasyon katsayısının en az 0,20 ve üzeri olması beklenmektedir. 0,20 ile 0,30 arasındaki sorular ise önem derecesine göre ölçekten çıkartılıp çıkartılmayacağına karar verilmelidir ve ayrıca korelasyonun 0,20 ve daha aşağısı ile negatif yönlü korelasyon olması durumlarında ki bu durumda ölçek toplanabilirlik özelliğini kaybedeceği için ilgili maddeler ölçekten çıkartılır. ${ }^{14} \mathrm{Bu}$ bilgiler doğrultusunda madde toplam korelasyonu 0,20 den aşağı olan ve negatif yüklenen maddeler ölçekten çıkartılmıştır. Ölçek iç tutarlılığı ve madde toplam korelasyona dayalı madde analizi neticesinde ölçekten iç tutarlılığı bozan 6 madde çıkarılmış ve ardından kalan maddeler ölçeğin yapı geçerliliğinin tespiti için AFA (Açımlayıcı Faktör Analizi) ile test edilmiştir. Maddelerin faktör analizine uygun olup olmadığının tespiti için ise öncelikle Kaiser-Meyer-Olkin (KMO) ve Bartlett Küresellik Testleri ile incelenmiştir. Bu testler ile birlikte ölçeğin faktör analizine uygun olduğu tespit edilmiş ve ardından açımlayıcı faktör analizi yapılmıştır. AFA sonucunda ise yük değeri 0.30 'dan düşük olan ve birden fazla faktörde 0.10 'dan daha az bir farkla yer alan maddeler bir madde olarak değerlendirildiğinden, bu özellikteki 3 madde de ölçekten çıkartılmıştır. ${ }^{15}$ Açımlayıcı faktör analizi sonuçlarını test etmek için

\footnotetext{
14 Yalçın Karagöz, SPSS AMOS META Uygulamalı İstatistiksel Analizler (Ankara: Nobel Yayıncılık, 2019), 1004.

15 Şener Büyüköztürk, Sosyal Bilimler İçin Veri Analizi El Kitabı (Ankara: Pegem Yayıncılık, 2002), 118-119 akt. Yalçın Karagöz, SPSS AMOS META Uygulamalı İstatistiksel Analizler, 1004.
} 
doğrulayıcı faktör analizi (DFA) yapılmıştır. Yapılan DFA neticesinde de bir madde ölçekten çlkartılarak ölçeğe son şekli verilmiş ve DFA model uyumu sonuçları raporlanmıştır.

HSÖ için yapılan açılayıcı faktör analizi neticesinde Kaiser-Meyer-Olkin (KMO) değeri: 0,884 olarak bulunmuştur. Bu değer kabul edilebilir kriter olarak belirtilen 0,50 'nin üzerindedir. ${ }^{16}$ Dolayısıyla örneklem büyüklügünün faktör analizi için "iyi" olduğu söylene-bilir. Ayrıca Bartlett Küresellik testi $\left(x^{2}{ }_{45}=912,409\right)$ olup $\mathrm{p}<0.001$ düzeyinde anlamlıdır. Bu sonuçlar ölçeğin ve örneklemin faktör analizine uygun olduğunu göstermektedir.

Tablo 1: KMO ve Bartlett Testi Sonuçları

\begin{tabular}{|l|l|l|}
\hline \multicolumn{2}{|c|}{ Kaiser-Meyer-Olkin Örneklem Uyumu } & 0,884 \\
\hline \multirow{3}{*}{ Bartlett Küresellik Testi } & $\mathrm{X}^{2}$ & 912,409 \\
\cline { 2 - 3 } & $\mathrm{Sd}$ & 45 \\
\cline { 2 - 3 } & $\mathrm{P}$ & 0,000 \\
\hline
\end{tabular}

Temel bileşenler analizi (principal component analysis) ve dik döndürme (varimax rotation) kullanılarak yapılan faktör analizi neticesinde öz değer olarak kabul edilen 1'den büyük iki faktör altında yüklenmiş olup varyansın \% 63,86'sını açıklamaktadır. Bulunan 2 faktöre ait öz değerler ve kümülatif varyans yüzdeleri ve her boyutun varyansın açıklama yüzdeleri aşağıdaki tabloda gösterilmektedir.

Tablo 2: Hadis ve Sünnet Algısı Ölçeğinin Açımlayıcı Faktör Analizi Sonuçları

\section{Açılanan Toplam Varyans}

\begin{tabular}{|c|c|c|c|c|c|c|c|c|c|}
\hline & \multicolumn{3}{|c|}{ Başlangıç Özdeğerleri } & \multicolumn{3}{|c|}{ Özet Kare yükleri } & \multicolumn{3}{|c|}{$\begin{array}{l}\text { Döndürme Sonrası } \\
\text { oluşan Kare Yükleri }\end{array}$} \\
\hline & $\begin{array}{l}\frac{\Xi}{\pi} \\
\frac{0}{2} \\
\stackrel{0}{0}\end{array}$ & 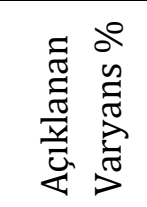 & $\begin{array}{l}\text { o̊ } \\
\frac{\pi}{\pi} \\
\frac{\pi}{2} \\
0 \\
\bullet\end{array}$ & 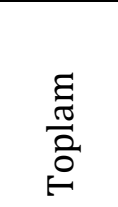 & 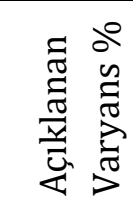 & $\begin{array}{l}0 \\
\Xi \\
\frac{\pi}{2} \\
0 \\
0 \\
0\end{array}$ & $\frac{\Xi}{\frac{\pi}{2}}$ & 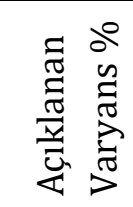 & $\begin{array}{l}\text { å } \\
\frac{\pi}{\pi} \\
\frac{0}{2} \\
0\end{array}$ \\
\hline 1 & $\begin{array}{l}5,08 \\
7\end{array}$ & 50,874 & $\begin{array}{l}50,87 \\
4\end{array}$ & 5,087 & 50,874 & $\begin{array}{l}50,87 \\
4\end{array}$ & $\begin{array}{l}4,65 \\
8\end{array}$ & 46,584 & $\begin{array}{l}46,58 \\
4\end{array}$ \\
\hline
\end{tabular}

16 Yusuf Genç- Arif Durğun, "Sağlık Çalışanlarının Dini Tutum Düzeyleri”, Sakarya Üniversitesi Illahiyat Fakültesi Dergisi 20/38 (Aralık 2018), 265. 


\begin{tabular}{|l|l|l|l|l|l|l|l|l|l|}
\hline $\mathbf{2}$ & $\begin{array}{l}1,29 \\
9\end{array}$ & 12,992 & $\begin{array}{l}63,86 \\
6\end{array}$ & 1,299 & 12,992 & $\begin{array}{l}63,86 \\
6\end{array}$ & $\begin{array}{l}1,72 \\
8\end{array}$ & 17,282 & $\begin{array}{l}63,86 \\
6\end{array}$ \\
\hline $\mathbf{3}$ &, 785 & 7,854 & $\begin{array}{l}71,72 \\
0\end{array}$ & & & & & & \\
\hline $\mathbf{4}$ &, 643 & 6,432 & $\begin{array}{l}78,15 \\
2\end{array}$ & & & & & & \\
\hline
\end{tabular}

Extraction Method: Principal Component Analysis.

Döndürme sonrası oluşan faktör yüklerine göre "duygu ve davranış" faktörü varyansın \%46,58'ini ve "bilgi" faktörü ise varyansın \%17,28'ini açıklamaktadır. Ölçeğin Cronbach's Alfa $(\alpha)$ değeri 0,879 ve "Duygu ve Davranış Alt Boyutu” 0,893 ve "Bilgi Alt Boyutu" 0,659 olarak hesaplanmıştır. Alfa değerleri için şu yorumlar yapılabilmektedir: ${ }^{17}$ Cronbach Alpha değeri $0,00 \leq \alpha \leq 0,40$ olduğu durumda ölçek güvenilir değil, $0,40 \leq \alpha \leq 0,60$ olduğu durumda ölçeğin güvenilirliği düşük, $0,60 \leq \alpha \leq 0,80$ ise ölçek oldukça güvenilir ve son olarak $\alpha \geq 0,80$ olması durumunda ise ölçek yüksek derecede güvenilirdir. Bu sonuçlar ölçeğin yüksek derecede güvenilir bir ölçek olduğunu göstermektedir.

Yapılan analizler sonrası belirlenen alt boyutlara giren maddeler ve bu maddelerin sayısı aşağıdaki Tablo 3'te verilmiştir:

Tablo 3: HSÖ Ölçeğinin Faktör Yükleri

\begin{tabular}{|l|l|l|}
\hline \multirow{2}{*}{ Maddeler } & \multicolumn{2}{|l|}{ Faktörler } \\
\cline { 2 - 3 } & $\begin{array}{l}\text { Duygu ve } \\
\text { Davranış Alt } \\
\text { Boyutu }\end{array}$ & $\begin{array}{l}\text { Bilgi Alt } \\
\text { Boyutu }\end{array}$ \\
\hline $\begin{array}{l}\text { Hz. Peygamber (sav) gibi yaşamak her Müslüman'ın } \\
\text { ideali olmalı. }\end{array}$ &, 911 & \\
\hline $\begin{array}{l}\text { Çocuklarıma Hz. Peygamberin (sav) davranış ve } \\
\text { düşüncelerini öğretmem gerektiğine inanıyorum. }\end{array}$ &, 867 & \\
\hline $\begin{array}{l}\text { Hz. Peygamberin (sav) anlayışı ve davranışlarının } \\
\text { hayatıma yansımasını istiyorum. }\end{array}$ &, 828 & \\
\hline Dinin sünnete ve Kuran'a dayandığı görüşündeyim. &, 807 & \\
\hline
\end{tabular}

17 Karagöz, SPSS AMOS META Uygulamalı İstatistiksel Analizler, 1003. 


\begin{tabular}{|l|l|l|}
\hline Ailemin Hz. Peygamberi (sav) tanımama katkısı oldu. &, 721 & \\
\hline Kuran'a inanmak sünnete bağlı kalmayı gerektirir. &, 677 &, 611 \\
\hline Hz. Peygamberi (sav) anlatan kitapları okudum. &, 532 &, 887 \\
\hline $\begin{array}{l}\text { "Hz. Peygamberin (sav) sünneti” denince aklıma ilk } \\
\text { önce sakal, sarık, tuzla yemeğe başlamak, oturarak su } \\
\text { içmek gibi şeyler geliyor. }\end{array}$ &, 784 \\
\hline $\begin{array}{l}\text { Hz. Peygamberin (sav) sünneti hakkındaki bilgilerim } \\
\text { yeterlidir. }\end{array}$ & & \\
\hline Hayatıma yön veren hadisleri yeterince biliyorum. & & \\
\hline
\end{tabular}

Açıklayıcı ya da diğer bir ifade ile açımlayıcı faktör analizi neticesinde Hadis ve Sünnet Algısı Ölçeği DFA (Doğrulayıcı Faktör Analizi) ile test edilmiş ve uyum indeksleri ile modifikasyon indekslerine bakılmıştır. Doğrulayıcı Faktör Analizi genellikle ölçek geliştirme ve geçerlilik analizlerinde kullanılmaktadır. Ayrıca açıklayıcı faktör analizi neticesinde belirlenen faktörlerin, hipotez ile belirlenen faktör yapılarına uygunluğunu test eden bir analizdir. ${ }^{18}$ Sonuç olarak DFA genellikle ölçek geliştirme ve geçerlilik analizlerinde kullanılır ve önceden belirlenmiş modelin doğruluğunu test etmeyi amaçlamaktadır. ${ }^{19}$ DFA sonucunda uyumu bozan bir madde de ölçekten çıkartılmış olup oluşan uyum değerleri: [ $(\chi 2(934,406, s d=45, p=0.000)$; $\chi 2$ / $\mathrm{sd}=2.612 ; \mathrm{RMSEA}=0.095 ; \mathrm{GFI}=0.912 ; \mathrm{AGFI}=0.858 ; \mathrm{CFI}=0.938 ; \mathrm{IFI}=0.939$; NFI=0.905; RFI=0.874; RMR=0,067 ] şeklinde tespit edilmiştir.

Tablo 4: Model Uyumuna İlişskin İndeks Değerleri

\begin{tabular}{|l|l|l|c|}
\hline Uyum Ölçüleri & İyi Uyum Değerleri & $\begin{array}{l}\text { Kabul Edilebilir } \\
\text { Uyum Değerleri }\end{array}$ & $\begin{array}{l}\text { Mevcut Modelin } \\
\text { Uyum Değerleri }\end{array}$ \\
\hline RMSEA & $0.00<$ RMSEA $<0.05$ & $0.05<$ RMSEA $<0.10$ & 0.095 \\
\hline RMR & $0.00<\mathrm{RMR}<0.05$ & $0.05<\mathrm{RMR}<0.10$ & 0.067 \\
\hline GFI & $0.95<\mathrm{GFI}<1.00$ & $0.90<\mathrm{GFI}<0.95$ & 0.912 \\
\hline AGFI & $0.90<\mathrm{AGFI}<1.00$ & $0.85<\mathrm{AGFI}<0.90$ & 0.858 \\
\hline
\end{tabular}

18 Mustafa Ataç- Burcu Öngen, "Doğrulayıcı Faktör Analizi İle Yeni Çevresel Paradigma Ölçeğinin Yapı Geçerliliğinin İncelenmesi", İstatistikçiler Dergisi: İstatistik ve Aktüerya 5/1 (Mart 2012), 16 akt. Yalçın Karagöz, SPSS AMOS META Uygulamalı İstatistiksel Analizler, 1067. 


\begin{tabular}{|l|l|l|c|}
\hline $\mathrm{NFI}$ & $0.95<\mathrm{NFI}<1.00$ & $0.90<\mathrm{NFI}<0.95$ & 0.905 \\
\hline $\mathrm{CFI}$ & $0.95<\mathrm{CFI}<1.00$ & $0.90<\mathrm{CFI}<0.95$ & 0.938 \\
\hline RFI & $0.90<\mathrm{RFI}<1.00$ & $0.85<\mathrm{RFI}<0.90$ & 0.874 \\
\hline
\end{tabular}

Tablo 4'e bakıldığında $\chi 2$ /sd oranı iyi uyum; RMR, GFI, AGFI, RFI, NFI ve CFI değerlerinin kabul edilebilir uyum gösterdiği anlaşılmaktadır. ${ }^{20}$ Doğrulayıcı faktör analizinin bağlantı diyagramı (path diagram) Şekil 1'de yer almaktadır.

\section{Şekil 1: Hadis ve Sünnet Algısı Ölçeğinin Path Diyagramı}

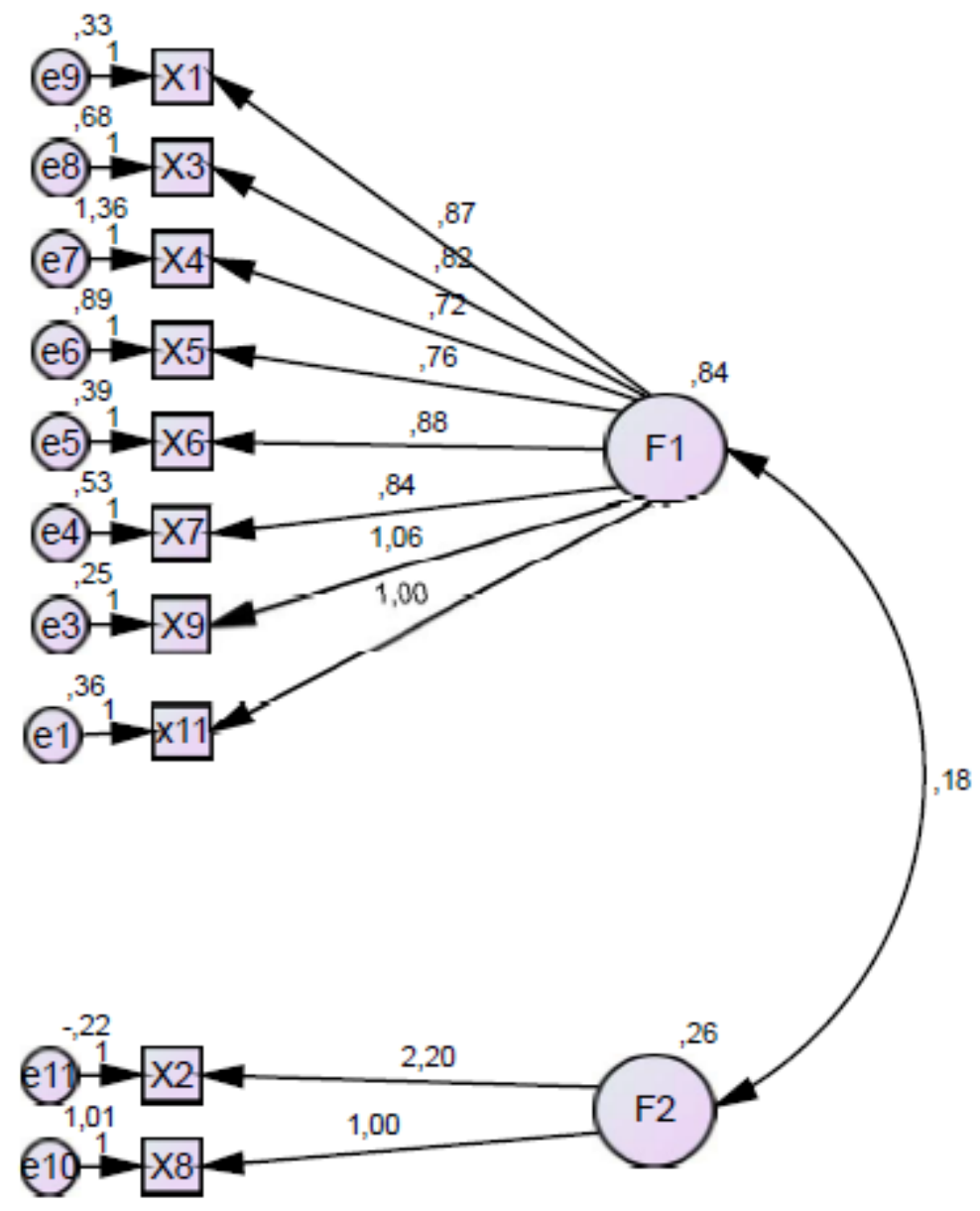

Kazım Özdamar, Eğitim Sağlık ve Davranış Bilimlerinde Ölçek ve Test Geliștirme Yapısal Eșitlik Modellemesi IBM SPSS, IBM SPSS AMOS ve MINITAB Uygulamalı (Eskişehir: Nisan Kitabevi, 2016), 185 akt. Turgay Şirin, "Maneviyat Ölçeği'nin Geliştirilmesi: Geçerlik ve Güvenirlik Çalıșması", 1300. 
Maneviyat Ölçeği ile ilgili olarak yapı geçerliliği çalışması Turgay Şirin tarafından gerçekleștirildiği için tekrar bir yapı geçerliği çalışması yapılmamıştır. Sadece ölçeğin Cronbach Alpha değerine bakılmış olup Cronbach's Alpha $(\alpha)=0,900$ olarak hesaplanmıştır. Bu da ölçeğin yüksek güvenilirlikte olduğunu göstermektedir.

\subsection{Demografik Özellikler}

Bu kısımda katılımcıların sosyo-demografik özelliklerine ve hadis ile sünnet algısına yönelik bulgulara ver verilecektir.

Tablo 5: Sosyo-Demografik Bilgiler $(n=178)$

\begin{tabular}{|c|c|c|c|c|c|}
\hline 1. Cinsiyet & $\mathbf{n}$ & $\%$ & 2. Bölüm & $\mathbf{n}$ & $\%$ \\
\hline Erkek & 39 & 21,9 & Sosyal Hizmetler & 80 & 44,9 \\
\hline Kadın & 139 & 78,1 & Sosyal Güvenlik & 46 & 25,8 \\
\hline 3. Sinif & $\mathbf{n}$ & $\%$ & İş Sağlığı ve Güvenliği & 48 & 27,0 \\
\hline 1. Sinıf & 75 & 42,1 & Bahçe Tarımı & 4 & 2,2 \\
\hline 2. Sinif & 103 & 57,9 & 4. Kalınan Yer & $\mathbf{n}$ & $\%$ \\
\hline 5. Anne Eğitim Durumu & $\mathbf{n}$ & $\%$ & Yurt & 130 & 73,0 \\
\hline Okuryazar değil & 9 & 5,1 & Evde tek & 3 & 1,7 \\
\hline İlkokul & 112 & 62,9 & Arkadaşlarla evde & 18 & 10,1 \\
\hline Ortaokul & 28 & 15,7 & Ailemle birlikte & 27 & 15,2 \\
\hline Lise & 26 & 14,6 & $\begin{array}{l}\text { 6. Baba Eğitim } \\
\text { Durumu }\end{array}$ & $\mathbf{n}$ & $\%$ \\
\hline Üniversite & 3 & 1,7 & İlkokul & 73 & 41,0 \\
\hline 7. Anne İș Durumu & $\mathbf{n}$ & $\%$ & Ortaokul & 50 & 28,1 \\
\hline Ev Hanımı & 151 & 85,3 & Lise & 47 & 26,4 \\
\hline Memur & 2 & 1,1 & Üniversite & 8 & 4,5 \\
\hline İşçi & 20 & 11,3 & 8. Baba İş Durumu & $\mathbf{n}$ & $\%$ \\
\hline Emekli & 4 & 2,3 & Memur & 6 & 3,4 \\
\hline
\end{tabular}




\begin{tabular}{|c|c|c|c|c|c|}
\hline 9. Ailenin Aylık Geliri & $\mathbf{n}$ & $\%$ & İşçi & 78 & 43,8 \\
\hline $0-1500$ & 23 & 12,9 & Esnaf & 24 & 13,5 \\
\hline $1501-3000$ & 89 & 50,0 & İşsiz & 20 & 11,2 \\
\hline $3001-4500$ & 46 & 25,8 & Emekli & 50 & 28,1 \\
\hline $4501-6000$ & 17 & 9,6 & $\begin{array}{l}\text { 10. Ailenin İkamet } \\
\text { Yeri }\end{array}$ & $\mathbf{n}$ & $\%$ \\
\hline 6001 ve üzeri & 3 & 1,7 & Köy & 28 & 15,7 \\
\hline 11. Öğrenim görülen lise & $\mathbf{n}$ & $\%$ & Kasaba & 7 & 3,9 \\
\hline Anadolu Lisesi & 69 & 38,8 & İlçe & 55 & 30,9 \\
\hline Anadolu İmam Hatip Lisesi & 35 & 19,7 & İl/ Şehir Merkezi & 31 & 17,4 \\
\hline $\begin{array}{l}\text { Mesleki ve Teknik Anadolu } \\
\text { Lisesi }\end{array}$ & 66 & 37,1 & $\begin{array}{l}\text { Büyükşehir } \quad \text { (30 } \\
\text { Büyükşehir) }\end{array}$ & 57 & 32,0 \\
\hline Genel Lise & 5 & 2,8 & $\begin{array}{l}\text { 12. Dini Bilgilerin } \\
\text { Edinildiği Kaynak }\end{array}$ & $\mathbf{n}$ & $\%$ \\
\hline Açık Öğretim Lisesi & 3 & 1,7 & Ailemden & 70 & 39,3 \\
\hline $\begin{array}{l}\text { 13. Hadis ve Sünnet } \\
\text { Kelimelerinin Anlamını } \\
\text { Bilme Durumu }\end{array}$ & $\mathbf{n}$ & $\%$ & Camiden & 17 & 9,6 \\
\hline Evet & 175 & 98,3 & $\begin{array}{ll}\text { Yaz } & \text { Kuran } \\
\text { Kurslarından } & \end{array}$ & 38 & 21,3 \\
\hline Hayır & 3 & 1,7 & $\begin{array}{ll}\text { Din } & \text { Kültürü } \\
\text { Dersinden } & \end{array}$ & 29 & 16,3 \\
\hline $\begin{array}{l}\text { 14. Sünnet ve Hadis } \\
\text { Kelimesinin } \\
\text { Çağrıştırdıkları }\end{array}$ & $\mathbf{n}$ & $\%$ & $\begin{array}{l}\text { Okuduğum } \\
\text { Kitaplardan }\end{array}$ & 8 & 4,5 \\
\hline Allah'ın (c.c) Buyrukları & 6 & 3,4 & Dini Sohbetlerden & 4 & 2,2 \\
\hline
\end{tabular}




\begin{tabular}{|l|l|l|l|l|l|}
\hline $\begin{array}{l}\text { Peygamberlere Gönderilen } \\
\text { Semavi Kitaplar /Kur'an, } \\
\text { İncil, Tevrat }\end{array}$ & 3 & 1,7 & Medyadan & 1 & 0,6 \\
\hline $\begin{array}{l}\text { Peygamber Efendimizin } \\
\text { (s.a.v) Söyledikleri ve } \\
\text { Yaptıkları }\end{array}$ & 168 & 94,4 & Diğer (Belirtiniz) & 11 & 6,2 \\
\hline Hiçbiri & 1 & 0,6 & Yaş Ortalaması & $\mathbf{2 0 , 4 7 \pm 1 , 8 8 7}$ \\
\hline
\end{tabular}

Katılımcılarımızın büyük çoğunluğunu kız öğrenciler oluşturmuştur. Yaş ortalaması $20,47 \pm 1,877$ ve yarısından fazlası 2 . Sınıf öğrencisidir.

Katılımcılarımızın yarısına yakını sosyal hizmetler programında öğrenim görmektedir. Öğrencilerin \%73'ü Yurtta kalmaktadır. Burada öğrencilerin daha ekonomik ve güvenli olduğu için yurdu tercih ettikleri söylenebilir. Öğrencilerimizin ebeveynlerinin eğitim düzeylerine bakıldığında katılımcılarımızın annelerinin eğitim düzeyinin yarısından fazlasının ilkokul mezunu, babalarının da yarısından biraz fazlasının ortaokul ve lise mezunu oldukları görülmektedir. Bu sonuç ebeveynlerin çeşitli sebeplerden ötürü eğitimlerini daha üst seviyeye taşıyamadıkları şeklinde yorumlanabilir. Katılımcıların ebeveynlerinin iş ve ailelerinin gelir durumuna bakıldığında annelerinin \%85;3'ünün ev hanımı, babalarının da yarıya yakınının iş̧̧i olduğu, gelir düzeylerinin ise \%50'sinin 1500- 3000 arasında olduğu tespit edilmiştir. Katılımcların ebeveynlerinin ikamet birimlerine baktığımızda ise \%32'sinin Büyükşehirlerde yaşadığı bulunmuştur. Bunun Bolu'nun Ankara ve İstanbul arasında konumlandığında kaynaklandığı düşünülebilir.

Öğrencilerin daha önce öğrenim gördükleri lise türüne baktığımızda ise yarısından fazlasının imam hatip lisesi ve mesleki ve teknik liseden mezun oldukları görülmektedir. Katılımcılarımızın dini bilgilerini en çok hangi kaynaktan aldığı sorusuna verilen cevaplara bakıldığında yarıya yakını ailesinden, \%30'unun da cami ve Kuran kurslarından dini bilgilerini edindikleri sonucuna ulaşılmıştır. Burada ailenin bireyleri toplumsallaştırma işlevinin etkili olduğunu söylemek yanlış olmaz. Zira aile kurumu, aileye yeni katılan çocuğun hayata yönelik bilgileri, davranış kalıplarını, inançları ve topyekûn toplumsal değer ve kültürü öğrenmeye başladığı yerdir. ${ }^{21}$ Öğrencilerin hadis ve sünnet kavramlarının ne anlama geldiğini bilip bilmediklerinin sorulduğu soruya verdikleri cevaplara bakıldığında \%98,3'ünün bu kavramların anlamını bildiklerini ifade etmişlerdir. En son olarak hadis ve sünnet kelimelerinin neleri çağrıştırdığı sorulmuş olup; \%94,4' ünün Peygamber Efendimizin (s.a.v.) söyledikleri ve yaptıkları cevabını verdikleri tabloda görülmektedir.

21 Memet Zencirkıran, Sosyoloji (Bursa: Dora Basım-Yayın Dağıtım, 2018), 164. 


\subsection{Hadis ve Sünnet Algısı İle Maneviyata İlişkin Bulgular}

Araştırmamızda ileri sürmüş olduğumuz hipotezlerin test edilmesi için birtakım ileri istatistik tekniklerinden yararlanılmıştır. Hangi tekniklerin veri setimiz için uygun olduğuna karar vermeden önce varyansların normal dağılım gösterip göstermediğine bakmak önem arz etmektedir. Bu nedenle öncelikle araştırmamızda kullanmış olduğumuz sürekli değişkenlerin normallik varsayımını sağlayıp sağlamadığına bakılmıştır. Aşağıdaki tabloda varyansların normal dağılım göstermediği görülmektedir.

Tablo 6: Normallik Testi Sonuçları

\begin{tabular}{|c|c|c|c|c|c|c|c|c|}
\hline & \multicolumn{3}{|c|}{$\begin{array}{l}\text { Kolmogorov- } \\
\text { Smirnova }\end{array}$} & \multicolumn{3}{|c|}{ Shapiro-Wilk } & \multirow{2}{*}{$\begin{array}{l}\text { Skewness } \\
\text { katsayısı }\end{array}$} & \multirow{2}{*}{$\begin{array}{l}\text { Kurtosis } \\
\text { katsayıs }\end{array}$} \\
\hline & Statistic & Df & Sig. & Statistic & df & Sig. & & \\
\hline $\begin{array}{l}\text { HSÖ (Duygu ve } \\
\text { Davranıș) }\end{array}$ & 0,158 & 178 & , 000 & 0,958 & 178 & ,000 & 0,135 & $-0,419$ \\
\hline $\begin{array}{l}\text { HSÖ (Bilgi Alt } \\
\text { Boyutu) }\end{array}$ & 0,178 & 178 & , 000 & 0,774 & 178 & ,000 & $-2,125$ & 5,047 \\
\hline Toplam HSÖ & 0,176 & 178 & ,000 & 0,810 & 178 & ,000 & $-1,958$ & 4,704 \\
\hline Toplam MÖ & 0,066 & 178 & ,054 & 0,957 & 178 & 000 & $-0,909$ & 2,020 \\
\hline
\end{tabular}

Verilerin normal dağılıp dağılmadığını test eden birçok test bulunmakla birlikte IBM SPSS programı yukarıda gösterilen testler ile analiz yapmaktadır. Veri sayısı $n \geq 29$ ise Kolmogorov-Smirnov, $n \leq 29$ olduğu durumlarda ise Shapiro-Wilk testi kullanılmaktadır. ${ }^{22} \mathrm{Bu}$ testlerde $\mathrm{p}<0.05$ olması durumunda normal dağılım varsayımını karşılamadığından nonparametrik testlerle analiz yapılması gerekmektedir. ${ }^{23} \mathrm{Bu}$ bilgiler ışığında ve yukardaki tabloda da görüldüğü üzere $\mathrm{p}$ değerleri 0.05 'den küçük olduğu hesaplanmıştır. Dolayısıyla nonparametrik testler kullanılacaktır. Anakütle dağılımı hakkında herhangi bir faraziyeye dayanmayan testlere "nonparametrik testler" ve yapılan analizlere de "nonparametrik istatistikler" denilmektedir. ${ }^{24} \mathrm{Bu}$ araştırmada da nonparametrik istatistikler kullanılmış olup, nominal değişkenlerde Mann-Whitney U testi kullanılırken ordinal değişkenlerde ise Kruskal-Wallis $\mathrm{H}$ testi kullanılmıștır. Kruskal-Wallis testinde anlamlı farklılık

Şeref Kalaycı vd., SPSS Uygulamalı Çok Değiş̧kenli İstatistik Teknikleri (Ankara: Asil Yayın Dağıtım, 2006), 10 akt. Yalçın Karagöz, SPSS AMOS META Uygulamalı İstatistiksel Analizler, 121.

23 Ayșegül Kaptanoğlu Yıldırım, Sağlık Alanında Hipotezden Teze: Veri Toplama ve Çözümleme Serüveni (İstanbul: Beşir Kitabevi, 2013), 82.

24 Karagöz, SPSS AMOS META Uygulamalı İstatistiksel Analizler, 1067. 
görüldüğünde farklılığın kaynağını tespit etmek için homojen dağılım olduğu durumlarda Tukey-HSD testi veya LSD testi, homojen dağılım olmadığı durumlarda da Tamhane's T2 testi kullanılmıștır. ${ }^{25}$

\subsection{1 Öğrencilerin Hadis ve Sünnet Algısı İle Maneviyat Düzeyleri ve Puanları}

Hadis ve Sünnet Algısı Ölçeği (HSÖ) öğrencilerin hadis ve sünnete ilişkin duygu davranış ve bilgilerini ölçmeyi amaçlayarak tasarlanmış ve standart hale getirilmiştir. Hadis ve Sünnet Algısını ölçen "Duygu ve Davranıș” ile "Bilgi” olmak üzere iki alt boyut vardır. Bu doğrultuda ölçekten alınan puanlar en düşük 10 en yüksek 50'dir. Puan yükseldikçe hadis ve sünnet algısı düzeyi de yükselmektedir. Ölçekte hadis ve sünnet algısı üç düzeyde değerlendirilmiş olup, alınan puanlar 10 (düşük) < 23-36 (Orta)< 37 (Yüksek) şeklinde kategorize edilerek değerlendirilmiştir. Bu doğrultuda katılımcılarımızın HSÖ puanı en az 10.00 ve en çok 50.00 ve ölçek ortalaması 38,59 7,67 olarak bulgulanmıştır. Katılımcı öğrencilerin kategorik olarak hadis ve sünnet algıları değerlendirildiğinde $\% 5,6$ 'sı düşük düzey, $\% 18,5^{\prime}$ i orta düzey ve geriye kalan $\% 75,8$ 'i ise yüksek düzeyde hadis ve sünnet algısına sahip oldukları bulunmuştur. Bu sonuçlar ve ortalama puanları da dikkate alındığında katılımcıların yüksek düzeyde hadis ve sünnet algısına sahip oldukları söylenebilir.

Katılımcıların maneviyat puanlarına bakıldığında ise en az 41,00 ve en yüksek

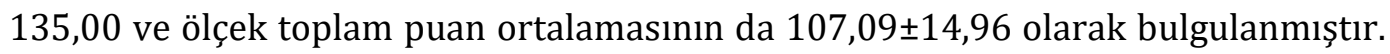
$\mathrm{Bu}$ bulgudan hareketle katılımcılarımızın maneviyat düzeylerinin de yüksek olduğunu söyleyebilir.

\subsubsection{Yaş Değişkenine Göre Hadis ve Sünnet Algısı ve Maneviyata İlişkin Farklılıklar}

Tablo 7'de katılımcıların yaş değişkeni ile hadis ve sünnet algısı arasında ve maneviyat puanları arsında anlamlı bir ilişkinin olup olmadığını tespit etmek için yapılan Spearman korelasyon sonucu görülmektedir.

Tablo 7: Korelasyon Analizi Sonucu

\begin{tabular}{|l|l|l|l|l|l|}
\hline \multicolumn{2}{|l|}{$\begin{array}{l}\text { Korelasyon } \\
\text { (Spearman) }\end{array}$} & $\begin{array}{l}\text { HSÖ } \\
\text { (Toplam) }\end{array}$ & HSÖ (Bilgi) & $\begin{array}{l}\text { HSÖ(Duygu ve } \\
\text { Davranış) }\end{array}$ & Maneviyat \\
\hline Yaş & $\mathrm{r}$ & 0,076 & 0,038 & 0,082 & 0,069 \\
\cline { 2 - 6 } & $\mathrm{p}$ & 0,312 & 0,615 & 0,278 & 0,360 \\
\hline
\end{tabular}

25 Murat Kayri, “Araştırmalarda Gruplar Arası Farkın Belirlenmesine Yönelik Çoklu Karşılaștırma (Post-Hoc) Teknikleri” Furat Üniversitesi Sosyal Bilimler Dergisi 19/1 (Ocak 2009) 51-64 akt. Yusuf Genç vd., "İnternet Kullanımının Üniversite Öğrencilerinin Yalnızlık Algılarına Etkileri", Akademik İncelemeler Dergisi 13/2 (2018), 320. 


\begin{tabular}{|l|l|l|l|l|l|}
\hline & $\mathrm{n}$ & 178 & 178 & 178 & 178 \\
\hline
\end{tabular}

Yukardaki tablo incelendiğinde katılımcıların yaş değişkenine göre gerek hadis ve sünnet algısı genel ve alt boyutlarında gerekse de maneviyat puanlarında anlamlı bir ilişkinin olmadığı görülmektedir. Dolayısıyla "Öğrencilerin yaşları ile sünnet ve hadis algısı arasında anlamlı bir ilişki vardır." Şeklindeki hipotezimiz doğrulanmamıştır. Bu sonucun çıkmasında öğrencilerin yaş dağılımlarının birbirine çok yakın olmasının önemli rol oynadığı düşünülmektedir.

\subsubsection{Cinsiyete Göre Hadis ve Sünnet Algısı ve Maneviyata İlişkin Farklılıklar}

Tablo 8'de katılımcılarımızın cinsiyet değişkenine göre hadis ve sünnet algısı ile maneviyatlarına ilişkin ölçek puanları üzerinden Mann-Whitney U testi analiz sonucu görülmektedir.

Tablo 8: Cinsiyet Değişkeni İle Hadis ve Sünnet Algısı ve Maneviyat İle İlgili Mann-Whitney U Testi

\begin{tabular}{|l|l|l|l|l|l|l|}
\hline \multicolumn{6}{|l|}{ Cinsiyet ile hadis ve sünnet algısı arasındaki anlam } \\
\hline Cinsiyet & N & $\begin{array}{l}\text { Sıra } \\
\text { Ortalama }\end{array}$ & $\begin{array}{l}\text { Sıra } \\
\text { Toplamı }\end{array}$ & U & Z & p \\
\hline Kız & 139 & 90,09 & 12522,00 & 2629,00 & $-0,287$ & 0,774 \\
\hline Erkek & 39 & 87,41 & 3409,00 & & & \\
\hline
\end{tabular}

Cinsiyet ile maneviyat arasındaki anlam

\begin{tabular}{|l|l|l|l|l|l|l|}
\hline Cinsiyet & N & $\begin{array}{l}\text { Sira } \\
\text { Ortalama }\end{array}$ & $\begin{array}{l}\text { Sira } \\
\text { Toplamı }\end{array}$ & U & Z & p \\
\hline Kız & 139 & 90,82 & 12623,50 & 2527,50 & $-0,644$ & 0,520 \\
\hline Erkek & 39 & 84,81 & 3307,50 & & & \\
\hline
\end{tabular}

Katılımcların cinsiyetleri bağlamında hadis ve sünnet algılarının ve maneviyatlarının anlamlı bir şekilde farklılaşıp farklılaşmadığını tespit etmek amacıyla Mann-Whitney U-Testi analizi kullanılmıştır. Analiz sonucunda p değeri 0,05'den büyük olduğu için anlamlı farklılık bulgulanmamıştır. Fakat her ne kadar istatistiksel olarak anlamlı farklılık bulgulanmamış olsa da gerek HSÖ'de gerekse de MÖ’de sıra ortalamalarına baktığımızda kız öğrencilerin puanlarının erkeklerden az 
da olsa daha yüksek olduğu görülmektedir. Ürkmez ${ }^{26}$ tarafından yapılan benzer bir araştırmada ise sünnet algısının sosyal kesimlere göre farklılık gösterdiği ve yaş, cinsiyet, meslek ve öğrenim durumu gibi bağımsız değişkenlerle bireylerin sünnet bilgisi ve kültürü arasında büyük ölçüde anlamlı bir ilişki bulunduğu bildirilmiştir. $\mathrm{Bu}$ çalışmada cinsiyet bazında elde ettiğimiz istatistiksel sonuç ile "Öğrencilerin cinsiyetleri ile sünnet ve hadis algısı arasında anlamlı bir ilişki vardır." șeklindeki hipotezimiz doğrulanmamıştır.

\subsection{4 Öğrenim Görülen Sınıfa Göre Hadis ve Sünnet Algısı ve Maneviyata İlişkin Farklılıklar}

Tablo 9'da Katılımcların okudukları veya bir başka ifadeyle öğrenim gördükleri sınıf düzeyine göre hadis ve sünnet algısı ile maneviyatlarına ilişkin ölçek puanları üzerinden Mann-Whitney U testi analiz sonucu görülmektedir.

Tablo 9: Sınıf Değişkeni İle Hadis ve Sünnet Algısı ve Maneviyat İle İlgili Mann-Whitney U Testi

\begin{tabular}{|l|l|l|l|l|l|l|}
\hline \multicolumn{6}{|l|}{ Sınıf düzeyi ile hadis ve sünnet algısı arasındaki anlam } \\
\hline Sınıf & N & $\begin{array}{l}\text { Sıra } \\
\text { Ortalama }\end{array}$ & $\begin{array}{l}\text { Sıra } \\
\text { Toplamı }\end{array}$ & U & Z & p \\
\hline 1. Sınıf & 75 & 91,59 & 6869,00 & 3706,00 & $-0,462$ & 0,644 \\
\hline 2. Sınıf & 103 & 87,98 & 9062,00 & & & \\
\hline
\end{tabular}

Sınıf düzeyi ile maneviyat arasındaki anlam

\begin{tabular}{|l|l|l|l|l|l|l|}
\hline Sinıf & N & $\begin{array}{l}\text { Sira } \\
\text { Ortalama }\end{array}$ & $\begin{array}{l}\text { Sira } \\
\text { Toplamı }\end{array}$ & U & Z & P \\
\hline 1. Sinıf & 75 & 83,25 & 6244,00 & 3394,00 & $-1,381$ & 0,167 \\
\hline 2. Sinıf & 103 & 94,05 & 9687,00 & & & \\
\hline
\end{tabular}

Katılımcıların okudukları sınıf değişkenine göre hadis ve sünnet algılarının ve maneviyatlarının anlamlı bir şekilde farklılaşıp farklılaşmadığını tespit etmek amacıyla Mann-Whitney U-Testi analizi kullanılmıştır. Analiz sonucunda $\mathrm{p}$ değeri 0,05'den büyük olduğu için anlamlı farklılık bulgulanmamıştır. Fakat her ne kadar istatistiksel olarak anlamlı farklılık bulgulanmamış olsa da HSÖ'de sıra ortalamalarına bakıldığında 1. sınıfların hadis ve sünnet algılarının az da olsa 2. Sınıflardan yüksek olduğu; MÖ'de yani maneviyat puanlarında ise 2. Sinıfların 1. Sinıflara nazaran daha yüksek puana sahip oldukları söylenebilir. Bu sonuç ile "Öğrencilerin okudukları sınıf

26 Ürkmez, “Sosyal Kesimler ve Sünnet Algıları Araştırması: Malatya (Hadis Alan Yorumu)”, 121. 
ile sünnet ve hadis algısı arasında anlamlı bir ilişki vardır." şeklindeki hipotezimiz doğrulanmamıştır.

\subsection{5 Öğrenim Görülen Program Değişkenine Göre Hadis ve Sünnet Algısı ve Maneviyata İlişkin Farklılıklar}

Kruskal Wallis H testi ordinal nitelikteki değişkene ait ortalamaları arasında anlamlı bir farklılık gösterip göstermediğinin tespit edilmesinde kullanılır ve parametrik testlerden ANOVA'nın nonparametrik test karşılığıdır. ${ }^{27} \mathrm{Bu}$ araştırmada ise ölçekler normal dağılım göstermediği (Kolmogorov-Smirnov=0.000, p<0.05) gerekçesiyle nonparametrik Kruskal Wallis $\mathrm{H}$ testi uygulanmıştır.

Tablo 10'da Katılımcıların okudukları program değişkenine göre hadis ve sünnet algısı ile maneviyatlarına ilişkin ölçek puanları üzerinden Kruskal Wallis H testi analiz sonucu görülmektedir.

Tablo 10: Bölüm Değişkeni İle Hadis ve Sünnet Algısı ve Maneviyat İle İlgili Kruskal Wallis H Testi

\begin{tabular}{|c|c|c|c|c|c|}
\hline \multicolumn{6}{|c|}{ Okunulan bölüm ile hadis ve sünnet algısı arasındaki anlam } \\
\hline Program & $\mathrm{N}$ & $\begin{array}{l}\text { Sira } \\
\text { Ortalama }\end{array}$ & SD & $x^{2}$ & $\mathrm{p}$ \\
\hline Sosyal Hizmetler & 80 & 92,40 & 3 & 7,703 & 0,053 \\
\hline Sosyal Güvenlik & 46 & 101,55 & & & \\
\hline $\begin{array}{l}\text { İș } \quad \text { Sağlığı } \quad \text { ve } \\
\text { Güvenliği }\end{array}$ & 48 & 73,04 & & & \\
\hline Bahçe Tarımı & 4 & 90,38 & & & \\
\hline \multicolumn{6}{|c|}{ Okunulan bölüm ile maneviyat arasındaki anlam } \\
\hline Program & $\mathrm{N}$ & $\begin{array}{l}\text { Sira } \\
\text { Ortalama }\end{array}$ & SD & $x^{2}$ & $\mathrm{p}$ \\
\hline Sosyal Hizmetler & 80 & 95,29 & 3 & 5,110 & 0,164 \\
\hline Sosyal Güvenlik & 46 & 84,13 & & & \\
\hline
\end{tabular}

27 Kaptanoğlu Yıldırım, Sağlık Alanında Hipotezden Teze: Veri Toplama ve Çözümleme Serüveni, 153. 


\begin{tabular}{|l|l|l|l|l|l|}
\hline $\begin{array}{l}\text { İş Sağlığı ve } \\
\text { Güvenliği }\end{array}$ & 48 & 81,61 & & & \\
\hline Bahçe Tarımı & 4 & 130,00 & & & \\
\hline
\end{tabular}

Katılımcıların okudukları program değişkenine göre hadis ve sünnet algısı puanlarının ve maneviyat skorlarının anlamlı bir şekilde farklılaşıp farklılaşmadığını test etmek amaciyla istatistiksel test tekniklerinden nonparametrik bir test olan Kruskal Wallis H Testi kullanılmıştır. Analiz neticesinde her iki ölçek puanı bazında istatistiksel olarak anlamlı farklılık bulgulanmamış olmasına rağmen tabloda hadis ve sünnet algısına ilişkin kısım incelendiğinde sıra ortalama değerlerine bakıldığında sosyal güvenlik programında okuyan öğrencilerin $(101,55)$ puanlarının diğer bölümlere göre daha yüksek olduğu görülmektedir. Bu durumda bu bölümdeki öğrencilerin hadis ve sünnet algısı diğer bölümlere nazaran daha yüksektir denilebilir. Bu sonuç ile "Öğrencilerin okudukları bölümler ile sünnet ve hadis algısı arasında anlamlı bir ilişki vardır." şeklindeki hipotezimiz doğrulanmamıștır.

\subsection{6 Öğrencilerin Kaldıkları Yer Değişkenine Göre Hadis ve Sünnet Algısı ve Maneviyata İlişkin Farklılıklar}

Tablo 11'de Katılımcıların kaldıkları yer değişkenine göre hadis ve sünnet algısı ile maneviyatlarına ilişkin ölçek puanları üzerinden Kruskal Wallis H testi analiz sonucu görülmektedir.

Tablo 11: Kalınan Yer Değiş̧eni İle Hadis ve Sünnet Algısı ve Maneviyat İle İlgili Kruskal Wallis H Testi

\begin{tabular}{|c|c|c|c|c|c|}
\hline Kalınan yer & $\mathrm{N}$ & $\begin{array}{l}\text { Sira } \\
\text { Ortalama }\end{array}$ & SD & $x^{2}$ & $\mathrm{p}$ \\
\hline Yurt & 130 & 90,17 & 3 & 0,488 & 0,922 \\
\hline Evde tek & 3 & 79,00 & & & \\
\hline $\begin{array}{l}\text { Arkadaşlarla } \\
\text { birlikte ev }\end{array}$ & 18 & 83,00 & & & \\
\hline Ailemle birlikte & 27 & 91,78 & & & \\
\hline \multicolumn{6}{|c|}{ Kalınan ile maneviyat arasındaki anlam } \\
\hline Program & $\mathrm{N}$ & $\begin{array}{l}\text { Sira } \\
\text { Ortalama }\end{array}$ & SD & $x^{2}$ & $\mathrm{p}$ \\
\hline
\end{tabular}




\begin{tabular}{|l|l|l|l|l|l|}
\hline Yurt & 130 & 90,71 & 3 & 5,421 & 0,143 \\
\hline Evde tek & 3 & 149,00 & & & \\
\hline $\begin{array}{l}\text { Arkadaşlarla } \\
\text { birlikte ev }\end{array}$ & 18 & 76,08 & & & \\
\hline Ailemle birlikte & 27 & 86,00 & & & \\
\hline
\end{tabular}

Yukarıdaki tabloda öğrencilerin eğitim sürecinde kaldıkları yer değişkenine göre hadis ve sünnet algısı puanlarının ve maneviyat skorlarının anlamlı bir şekilde farklılaşıp farklılaşmadığını test etmek amacıyla kullanılan Kruskal Wallis $\mathrm{H}$ Testi sonucu görülmektedir. Analiz neticesinde $\mathrm{p}<0,05$ düzeyinde anlamlı bir farklılık bulgulanmamıştır. Bu sonuç "Öğrencilerin ikamet ettikleri yer ile sünnet ve hadis algısı arasında anlamlı bir ilişki vardır." şeklindeki hipotezimizi doğrulamamıştır.

\subsection{7 Öğrencilerin Annelerinin Eğitim Düzeylerine Göre Hadis ve Sünnet Algısı ve Maneviyata İlişkin Farklılıklar}

Tablo 12'de Katılımcıların annelerinin eğitim durumları değişkenine göre hadis ve sünnet algısı ile maneviyatlarına ilişkin ölçek puanları üzerinden Kruskal Wallis H testi analiz sonucu görülmektedir.

Tablo 12: Anne Eğitim Düzeyi Değişkeni İle Hadis ve Sünnet Algısı ve Maneviyat İle İlgili Kruskal Wallis H Testi

\begin{tabular}{|c|c|c|c|c|c|c|}
\hline \multicolumn{2}{|c|}{ Anne eğitim düzeyi } & \multirow{2}{*}{$\begin{array}{l}\text { N } \\
9\end{array}$} & \multirow{2}{*}{$\begin{array}{l}\begin{array}{l}\text { Sira } \\
\text { Ortalama }\end{array} \\
123,78\end{array}$} & \multirow{2}{*}{$\begin{array}{l}\text { SD } \\
4\end{array}$} & \multirow{2}{*}{$\begin{array}{c}x^{2} \\
11,793\end{array}$} & \multirow{2}{*}{$\begin{array}{l}\mathrm{p} \\
\mathbf{0 , 0 1 9}\end{array}$} \\
\hline \multirow{5}{*}{ 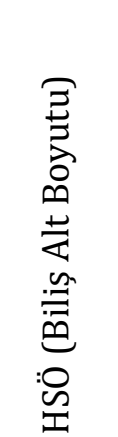 } & Okuryazar değil & & & & & \\
\hline & İlkokul & 112 & 89,85 & & & \\
\hline & Ortaokul & 28 & 80,88 & & & \\
\hline & Lise & 26 & 94,31 & & & \\
\hline & Üniversite & 3 & 12,33 & & & \\
\hline & Okuryazar değil & 9 & 118,50 & 4 & 9,758 & $0,045^{*}$ \\
\hline : & İlkokul & 112 & 89,43 & & & \\
\hline
\end{tabular}




\begin{tabular}{|c|c|c|c|c|c|c|}
\hline & Ortaokul & 28 & 84,96 & & & \\
\hline & Lise & 26 & 93,40 & & & \\
\hline & Üniversite & 3 & 13,67 & & & \\
\hline \multirow{5}{*}{ 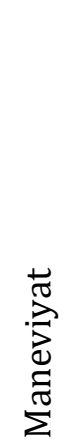 } & Okuryazar değil & 9 & 109,28 & 3 & 7,746 & 0,101 \\
\hline & İlkokul & 112 & 94,64 & & & \\
\hline & Ortaokul & 28 & 77,43 & & & \\
\hline & Lise & 26 & 79,15 & & & \\
\hline & Üniversite & 3 & 40,50 & & & \\
\hline
\end{tabular}

${ }^{*} \mathbf{p}<0,05$

Katılımcı öğrencilerin annelerinin eğitim düzeyi değişkenine göre hadis ve sünnet algısı ve maneviyat puanları ile anlamlı bir ilişki olup olmadığının tespiti için yapılan Kruskal Wallis $\mathrm{H}$ testi sonucuna göre Anne eğitim düzeyi ile HSÖ biliş alt boyutu arasında $\left(x^{2}{ }_{(4.178)}=11,793 ; \mathrm{p}=0,019 ; \mathrm{p}<0.05\right)$ ve HSÖ toplam puanları arasında $\left(x_{(4.178)}^{2}=9,758 ; \mathrm{p}=0,045 ; \mathrm{p}<0.05\right)$ anlamlı farklılık bulgulanmıştır.

Farklılı̆̆n kaynağını tespit etmek amacıyla PostHoc testlerinden faydalanılmaktadır. PostHoc testlerinden hangisinin kullanılacağına karar verebilmek için varyansların homojen bir dağılım gösterip göstermediğine bakılması gerekmektedir. Varyansların homojenlik durumuna "Levene" istatistiği ile bakılmaktadır. Varyanslar HSÖ bilgi alt boyutunda (Levene $=0,595 ; \mathrm{p}=0.667 ; \mathrm{p}>0.05$ ) ve HSÖ toplam puanda (Levene $=0,394 ; p=0,813 ; p>0.05$ ) homojen dağılım gösterdiği için PostHoc testlerinden Tukey HSD testi kullanılmıştır. Analiz neticesinde HSÖ bilgi alt boyutunda Üniversite mezunu= 19,66 ile Okuryazar değil=36,00 arasında ve İlkokul mezunu=32,57 ve ortaokul mezunu $=31,53$ ve lise mezunu=32,88 arasında farklılığın kaynaklandığı tespit edilmiştir. Bu sonuç ile Öğrencilerin annelerinin eğitim durumu ile sünnet ve hadis algısı arasında anlamlı bir ilişki vardır, şeklindeki hipotezimiz doğrulanmıştır.

\subsection{8 Öğrencilerin Babalarının Eğitim Düzeylerine Göre Hadis ve Sünnet Algısı ve Maneviyata İlişkin Farklılıklar}

Tablo 13'te Katılımcların annelerinin eğitim durumları değişkenine göre hadis ve sünnet algısı ile maneviyatlarına ilişkin ölçek puanları üzerinden Kruskal Wallis H testi analiz sonucu görülmektedir. 
Tablo 13: Baba Eğitim Düzeyi Değişkeni İle Hadis ve Sünnet Algısı ve Maneviyat İle İlgili Kruskal Wallis H Testi

\begin{tabular}{|c|c|c|c|c|c|c|}
\hline \multicolumn{7}{|c|}{ Baba eğitim düzeyi ve maneviyat ile hadis ve sünnet algısı arasındaki anlam } \\
\hline \multicolumn{2}{|c|}{ Baba eğitim düzeyi } & \multirow{2}{*}{$\begin{array}{l}\mathrm{N} \\
73\end{array}$} & \multirow{2}{*}{$\begin{array}{l}\begin{array}{l}\text { Sira } \\
\text { Ortalama }\end{array} \\
91,98\end{array}$} & \multirow{2}{*}{$\begin{array}{l}\text { SD } \\
3\end{array}$} & \multirow{2}{*}{$\begin{array}{c}x^{2} \\
3,311\end{array}$} & \multirow{2}{*}{$\begin{array}{l}p \\
0,346\end{array}$} \\
\hline \multirow[b]{4}{*}{$\begin{array}{l}0 \\
\mathscr{N} \\
\text { \& }\end{array}$} & İlkokul & & & & & \\
\hline & Ortaokul & 50 & 83,46 & & & \\
\hline & Lise & 47 & 96,09 & & & \\
\hline & Üniversite & 8 & 65,94 & & & \\
\hline \multirow{4}{*}{ 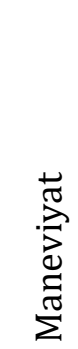 } & İlkokul & 73 & 97,24 & 3 & 3,711 & 0,294 \\
\hline & Ortaokul & 50 & 86,94 & & & \\
\hline & Lise & 47 & 83,83 & & & \\
\hline & Üniversite & 8 & 68,19 & & & \\
\hline
\end{tabular}

Yapılan analiz neticesinde katılımcıların babalarının eğitim düzeyi ile hadis ve sünnet algısı ve maneviyat puanları arasında anlamlı bir ilişki yoktur. Dolayısıyla "Öğrencilerin babalarının eğitim durumu ile sünnet ve hadis algısı arasında anlamlı bir ilişki vardır." şeklindeki hipotezimiz doğrulanmamıştır.

\subsection{9 Öğrencilerin Aile Yapıları Değişkenine Göre Hadis ve Sünnet Algısı ve Maneviyata İlişkin Farklılıklar}

Tablo 14'te Katılımcıların aile yapıları değișkenine göre hadis ve sünnet algısı ile maneviyatlarına ilişkin ölçek puanları üzerinden Kruskal Wallis H testi analiz sonucu görülmektedir.

Tablo 14: Aile Yapısı Değişkeni İle Hadis ve Sünnet Algısı ve Maneviyat İle İlgili Kruskal Wallis H Testi

Aile yapısı değişkenine göre maneviyat, hadis ve sünnet algısı arasındaki anlam

\begin{tabular}{|l|l|l|l|l|l|l|}
\hline \multicolumn{2}{|l|}{ Aile Yapısı } & $\mathrm{N}$ & $\begin{array}{l}\text { Sira } \\
\text { Ortalama }\end{array}$ & SD & $x^{2}$ & $\mathrm{p}$ \\
\hline $\boldsymbol{I}: 0$ & Çekirdek aile & 136 & 86,86 & 2 & 1,949 & 0,377 \\
\hline
\end{tabular}




\begin{tabular}{|l|l|l|l|l|l|l|}
\hline & Geniş aile & 37 & 99,96 & & & \\
\cline { 2 - 7 } & Tek ebeveynli aile & 5 & 83,90 & & & \\
\hline \multirow{2}{*}{} & Çekirdek aile & 136 & 86,85 & 2 & 4,469 & 0,107 \\
\cline { 2 - 7 } & Geniș aile & 37 & 103,09 & & & \\
\cline { 2 - 5 } & Tek ebeveynli aile & 5 & 61,00 & & & \\
\hline
\end{tabular}

Yapılan analiz neticesinde aile yapısı değişkenine göre gerek maneviyat puanlarında gerekse de hadis ve sünnet algısı puanlarında anlamlı bir farklılık bulgulanmamıştır. Her ne kadar istatistiksel olarak anlamlı bir farklılık bulgulanmamış olsa da geleneksel geniş aileden gelen katılımcıların sıra ortalama puanlarının diğer aile yapılarından gelen öğrencilere göre daha fazla olduğu görülmektedir. Bu sonuç ile "Öğrencilerin aile yapıları ile sünnet ve hadis algısı arasında anlamlı bir ilişki vardır." șeklindeki hipotezimiz doğrulanmamıștır.

\subsubsection{0 Öğrencilerin Ailelerinin İkamet Yer Değişkenine Göre Hadis ve Sünnet Algısı ve Maneviyata İlişkin Farklılıklar}

Tablo 15'te Katılımcıların ailelerinin ikamet ettikleri yer değișkenine göre hadis ve sünnet algısı ile maneviyatlarına ilişkin ölçek puanları üzerinden Kruskal Wallis H testi analiz sonucu görülmektedir.

Tablo 15: Aile İkamet Yeri Değişkeni İle Hadis ve Sünnet Algısı ve Maneviyat İle İlgili Kruskal Wallis H Testi

\begin{tabular}{|c|c|c|c|c|c|c|}
\hline Aile İ & amet Birimi & $\mathrm{N}$ & Sira & SD & $x^{2}$ & $\mathrm{p}$ \\
\hline & Köy & 28 & 97,07 & 4 & 1,040 & 0,904 \\
\hline & Kasaba & 7 & 84,50 & & & \\
\hline & İlçe & 55 & 87,08 & & & \\
\hline & İl/ Șehir Merkezi & 31 & 92,61 & & & \\
\hline $\begin{array}{l}0 \\
0 \\
\text { I }\end{array}$ & $\begin{array}{l}\text { Büyükşehir ( } 30 \text { Büyükşehir İl } \\
\text { ve İlçeler) }\end{array}$ & 57 & 87,04 & & & \\
\hline
\end{tabular}




\begin{tabular}{|c|c|c|c|c|c|c|}
\hline \multirow{5}{*}{ 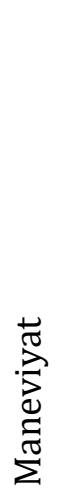 } & Köy & 28 & 101,43 & 4 & 2,938 & 0,568 \\
\hline & Kasaba & 7 & 71,64 & & & \\
\hline & İlçe & 55 & 85,77 & & & \\
\hline & İl/ Şehir Merkezi & 31 & 93,58 & & & \\
\hline & $\begin{array}{l}\text { Büyükşehir (30 Büyükșehir İl } \\
\text { ve İlçeler) }\end{array}$ & 57 & 87,21 & & & \\
\hline
\end{tabular}

Yapılan analiz neticesinde katılımcıların ailelerinin yerleşim birimi ya da ikamet ettikleri yer değișkenine göre gerek maneviyat puanlarında gerekse de hadis ve sünnet algısı puanlarında anlamlı bir farklılık bulgulanmamıștır. Her ne kadar istatistiksel olarak anlamlı bir farklılık bulgulanmamış olsa da "Köy" yerleşim biriminde ikamet eden aileden gelen katılımcıların sıra ortalama puanlarının diğer yerleşim birimlerinden gelen öğrencilere göre daha fazla olduğu görülmektedir. Bu sonuç ile "Öğrencilerin ailelerinin ikamet ettikleri yer ile sünnet ve hadis algısı arasında anlamlı bir ilişki vardır." şeklindeki hipotezimiz doğrulanmamıştır.

\subsubsection{1 Öğrencilerin Öğrenim Gördükleri Lise Türü Değișkenine Göre Hadis ve Sünnet Algısı ve Maneviyata İlişkin Farklılıklar}

Tablo 16'da Katılımcıların daha önce öğrenim görmüş oldukları lise türü değişkenine göre hadis ve sünnet algısı ile maneviyatlarına ilişkin ölçek puanları üzerinden Kruskal Wallis H testi analiz sonucu görülmektedir.

Tablo 16: Lise Türü Değişkeni İle Hadis ve Sünnet Algısı ve Maneviyat İle İlgili Kruskal Wallis H Testi

Öğrencilerin lise türü değişkenine göre maneviyat, hadis ve sünnet algısı arasındaki anlam

\begin{tabular}{|c|c|c|c|c|c|c|}
\hline \multicolumn{2}{|c|}{ Lise türü } & \multirow{2}{*}{\begin{tabular}{|l|}
$\mathrm{N}$ \\
69
\end{tabular}} & \multirow{2}{*}{$\begin{array}{l}\begin{array}{l}\text { Sira } \\
\text { Ortalama }\end{array} \\
95,67\end{array}$} & \multirow{2}{*}{$\begin{array}{l}\text { SD } \\
4\end{array}$} & \multirow{2}{*}{$\begin{array}{c}x^{2} \\
10,800\end{array}$} & \multirow{2}{*}{$\begin{array}{l}\mathrm{p} \\
\mathbf{0 , 0 2 9}\end{array}$} \\
\hline \multirow{4}{*}{ 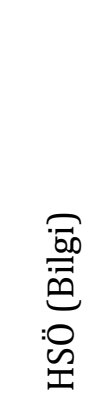 } & Anadolu Lisesi & & & & & \\
\hline & Anadolu İmam Hatip Lisesi & 35 & 104,07 & & & \\
\hline & $\begin{array}{l}\text { Mesleki ve Teknik Anadolu } \\
\text { Lisesi }\end{array}$ & 66 & 75,69 & & & \\
\hline & Genel Lise & 5 & 65,60 & & & \\
\hline
\end{tabular}




\begin{tabular}{|c|c|c|c|c|c|c|}
\hline & Açıköğretim Lisesi & 3 & 121,17 & & & \\
\hline \multirow{5}{*}{ 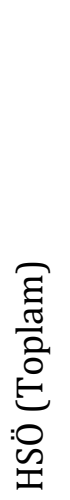 } & Anadolu Lisesi & 28 & 95,14 & 4 & 9,341 & 0,053 \\
\hline & Anadolu İmam Hatip Lisesi & 7 & 105,31 & & & \\
\hline & $\begin{array}{l}\text { Mesleki ve Teknik Anadolu } \\
\text { Lisesi }\end{array}$ & 55 & 76,52 & & & \\
\hline & Genel Lise & 31 & 67,50 & & & \\
\hline & Açıköğretim Lisesi & 57 & 97,50 & & & \\
\hline \multirow{5}{*}{ 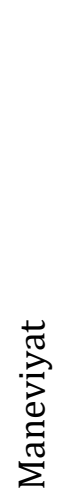 } & Anadolu Lisesi & 28 & 86,16 & 4 & 4,687 & 0,321 \\
\hline & Anadolu İmam Hatip Lisesi & 7 & 103,89 & & & \\
\hline & $\begin{array}{l}\text { Mesleki ve Teknik Anadolu } \\
\text { Lisesi }\end{array}$ & 55 & 87,58 & & & \\
\hline & Genel Lise & 31 & 60,60 & & & \\
\hline & Açıköğretim Lisesi & 57 & 88,83 & & & \\
\hline
\end{tabular}

${ }^{*} \mathbf{p}<0,05$

Yapılan analiz neticesinde öğrencilerin daha önce mezun oldukları lise türü bağlamında HSÖ ve Maneviyat puanlarının anlamlı bir şekilde farklılaşıp farklılaşmadığına bakıldığında HSÖ toplam puanında $p=0,053$ ve maneviyat puanlarında $\mathrm{p}=0,321$ ile istatistiksel olarak anlamlı bir şekilde farklılaşmazken, HSÖ biliş alt boyutunda lise türü değişkeni arasında $\left(x^{2}{ }_{(4.178)}=10,800 ; p=0,029 ; p<0.05\right)$ anlamlı farklılık bulunmuștur.

Varyanslar homojen (Levene $=1,648 ; p=0,164 ; p>0.05$ ) dağılım gösterdiği için farklılığın kaynağını tespit etmek amacıyla PostHoc testlerinden Tukey HSD testi kullanılmıştır. Analiz neticesinde HSÖ bilgi alt boyutunda Anadolu İmam Hatip Lisesi= 34,42 ile Mesleki ve Teknik Anadolu Lisesi=30,54 arasında anlamlı farklılığın kaynaklandığı bulgulanmıştır. Bu sonuç ile "Öğrencilerin öğrenim görmüş oldukları lise türü ile sünnet ve hadis algısı arasında anlamlı bir ilişki vardır." şeklindeki hipotezimiz kısmen doğrulanmıştır. 
2.3.12 Öğrencilerin Dini Bilgilerini En Çok Nereden Aldıkları Değişkenine Göre Hadis ve Sünnet Algısı ve Maneviyata İliş̧in Farklılıklar

Tablo 17'de Katılımcıların dini bilgilerini en çok nereden aldıklarına ya da hangi kaynaktan beslendiklerine ilişkin değişkene göre hadis ve sünnet algısı ile maneviyatlarına ilişkin ölçek puanları üzerinden Kruskal Wallis H testi analiz sonucu görülmektedir.

Tablo 17: Dini Bilgi Edinim Değişkeni İle Hadis ve Sünnet Algısı ve Maneviyat İle İlgili Kruskal Wallis H Testi

\begin{tabular}{|c|c|c|c|c|c|c|}
\hline \multicolumn{2}{|c|}{ Dini bilgilerin kaynağı } & $\mathrm{N}$ & & SD & $x^{2}$ & $\mathrm{p}$ \\
\hline \multirow{7}{*}{ 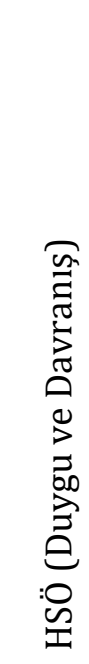 } & Ailemden & 70 & 98,21 & 6 & 14,006 & $0,030^{*}$ \\
\hline & Camiden & 17 & 66,82 & & & \\
\hline & Yaz Kuran Kurslarından & 38 & 95,58 & & & \\
\hline & Din Kültürü Dersinden & 29 & 82,10 & & & \\
\hline & Okuduğum Kitaplardan & 8 & 114,88 & & & \\
\hline & Dini Sohbetlerden & 4 & 45,50 & & & \\
\hline & Diğer & 12 & 67,17 & & & \\
\hline \multirow{7}{*}{ 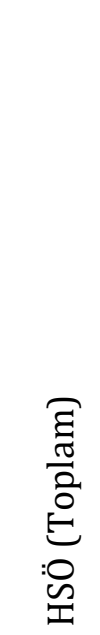 } & Ailemden & 70 & 100,79 & 6 & 15,401 & $0,017^{*}$ \\
\hline & Camiden & 17 & 73,00 & & & \\
\hline & Yaz Kuran Kurslarından & 38 & 94,21 & & & \\
\hline & Din Kültürü Dersinden & 29 & 67,52 & & & \\
\hline & Okuduğum Kitaplardan & 8 & 116,38 & & & \\
\hline & Dini Sohbetlerden & 4 & 53,00 & & & \\
\hline & Diğer & 12 & 79,50 & & & \\
\hline
\end{tabular}




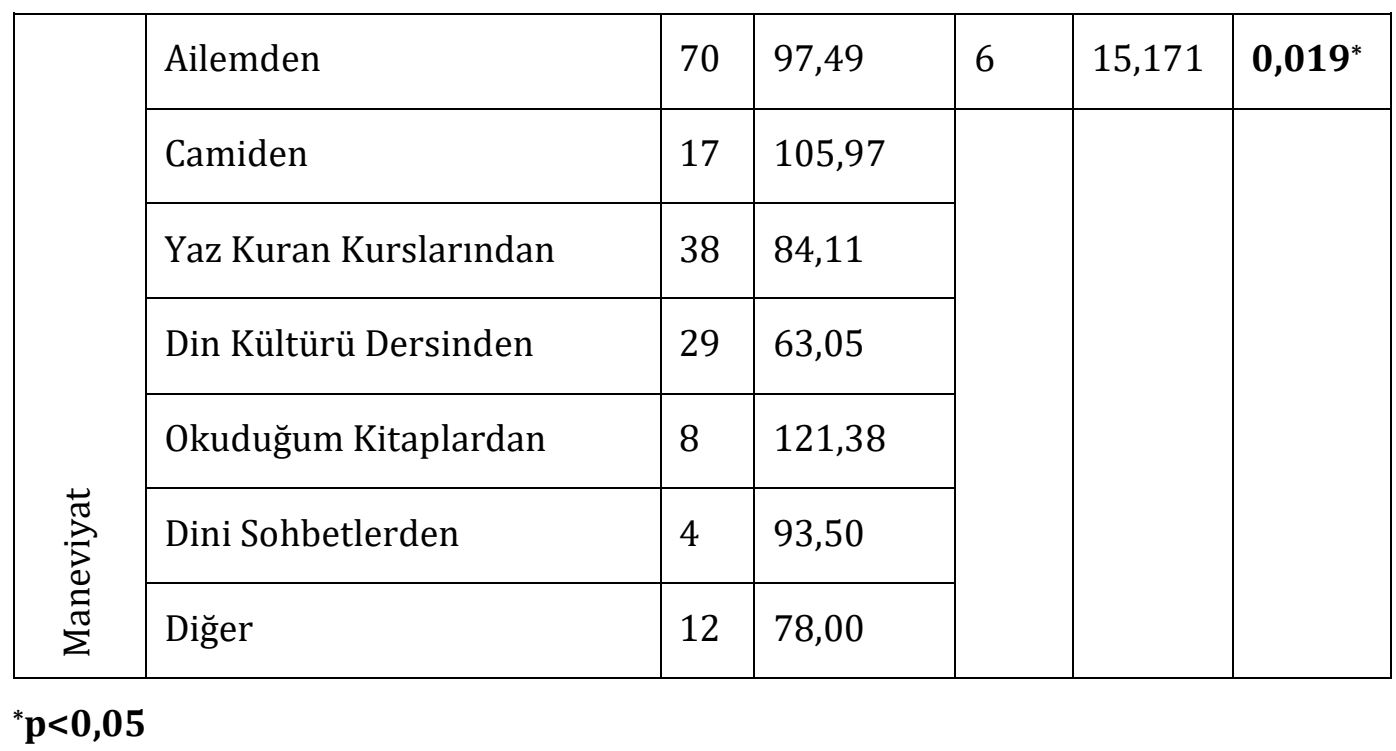

Katılımcı öğrencilerin dini bilgilerini en çok nereden veya hangi kaynaktan aldıklarına ilişkin sorulan anket sorusunda öğrencilerden en çok 1 seçenek işaretlenmesi istenmiştir. Burada güdülen amaç öğrencilerin mevcut dini bilgilerini en fazla hangi kanaldan aldıklarının belirlenmesine yöneliktir. Böylece öğrencilerin dini bilgilerinin beslendiği kaynak ile hadis ve sünnet algısında ve maneviyat durumlarında anlamlı bir farklılığın olup olmadığı anlaşılmak istenmiştir. Yaplan analiz neticesinde yukarıdaki tabloda da görüleceği üzere HSÖ duygu ve davranış alt boyutunda $\left(x^{2}{ }_{(6.178)}=14,006 ; \mathrm{p}=0,030 ; \mathrm{p}<0.05\right)$, HSÖ toplam ölçek puanı ile dini bilgilerin kaynağı değişkeni arasında $\left(x^{2}{ }_{(6.178)}=15,401 ; \mathrm{p}=0,017 ; \mathrm{p}<0.05\right)$ ve son olarak maneviyat puanları ile dini bilgilerin kaynağı değişkeni arasında $\left(x^{2}{ }_{(6.178)}=\right.$ 15,171; $\mathrm{p}=0,019 ; \mathrm{p}<0.05$ ) anlamlı farklılıklar bulgulanmıștır.

Varyanslar HSÖ (Levene $=1,005 ; p=0,424 ; p>0.05$ ) toplam puanında, HSÖ duygu ve davranış alt boyutunda (Levene $=0,536 ; \mathrm{p}=0,164 ; \mathrm{p}>0.05$ ) ve Maneviyat ölçeğinde (Levene $=0,887 ; p=0,506 ; p>0.05$ ) homojen dağılım gösterdiği için farklılığın kaynağını tespit etmek için yaygın olarak kullanılan PostHoc testlerinden LSD testi kullanılmıştır. PostHoc analizi neticesinde HSÖ duygu ve davranış alt boyutunda ailemden $=6,48$ ile camiden $=5,35$ arasında; yaz kuran kurslarından $=6,42$ ile camiden=5,35 arasında anlamlı farklılığın kaynaklandığı, HSÖ ölçek toplam puanında ailemden $=39,52$ ile dini sohbetlerden $=31,50$ arasında; yaz Kuran kurslarından=39,63 ile dini sohbetlerden=31,50 arasında; okuduğum kitaplardan=41,12 ile dini sohbetlerden=31,50 arasında anlamlı farklılığın kaynaklandığı ve son olarak maneviyat puanlarında ise din kültürü dersinden=99,17 ile ailemden $=109,10$ ve Camiden $=112,05$ ve okuduğum kitaplardan $=116,12$ arasında anlamlı farklılığın kaynaklandığı bulgulanmıştır. Bu analiz neticesinde gerek hadis ve sünnet algısında gerekse de maneviyat algısında olsun ailenin, yaz kuran kurslarının ve dini içerikli yayınların bireylerin maneviyatlarında ve hadis ve sünnet algılarında önemli bir rol oynadığı söylenebilir. Ürkmez tarafından gerçekleştirilen benzer bir çalışmada ise dini konularda okuma ve tartışmaların sünnetin niteliği 
konusunda toplumun yeterli bilgiye sahip olduğu sonucuna ulaşılmıştır. ${ }^{28}$ Burada da dini okumaların maneviyat ve sünnet algısında önemli bir yere sahip olduğunu ve bu iki araştırmanın birbirini desteklediğini söyleyebiliriz. Bu sonuçla “Öğrencilerin dini bilgilerini aldıkları kaynaklar ile sünnet ve hadis algısı arasında anlamlı bir ilişki vardır." şeklindeki hipotezimiz doğrulanmıştır.

\subsubsection{Maneviyat ve Sünnet Algısı Arasındaki İlişki}

Hadis ve sünnet algısı veya hadis ve sünnete ilişkin bireylerin bilgi düzeyleri ile maneviyata ilişkin tutumları arasında anlamlı bir ilişkinin olup olmadığını belirlemek maksadıyla korelasyon analizi yapılmıştır. Korelasyon analizi bilimsel çalışmalarda değişkenler arasında ilişkinin olup olmadığını eğer bir ilişki varsa bunun gücünün ve yönünün belirlenmesi için sıklıkla kullanılmaktadır. ${ }^{29}$

Tablo 18: Maneviyat ve HSÖ Arasındaki Korelasyon

\begin{tabular}{|c|c|c|c|c|c|}
\hline \multicolumn{2}{|l|}{$\begin{array}{l}\text { Korelasyon } \\
\text { (Spearman) }\end{array}$} & \multirow{2}{*}{$\begin{array}{l}\text { HSÖ (Bilgi) } \\
1,000\end{array}$} & \multirow{2}{*}{$\begin{array}{l}\text { HSÖ (Duygu } \\
\text { ve } \\
\text { Davranış) }\end{array}$} & \multirow[t]{2}{*}{ HSÖ(Toplam) } & \multirow[t]{2}{*}{ Maneviyat } \\
\hline HSÖ (Bilgi) & $\mathrm{r}$ & & & & \\
\hline & $\mathrm{p}$ & & & & \\
\hline & $\mathrm{n}$ & 178 & & & \\
\hline \multirow{3}{*}{$\begin{array}{l}\text { HSÖ(Duygu } \\
\text { ve } \\
\text { Davranış) }\end{array}$} & $\mathrm{r}$ & 0,288 & 1,000 & & \\
\hline & $\mathrm{p}$ & 0,000 & & & \\
\hline & $\mathrm{n}$ & 178 & 178 & & \\
\hline \multirow{3}{*}{$\begin{array}{l}\text { HSÖ } \\
\text { (Toplam) }\end{array}$} & r & 0,932 & 0,581 & 1,000 & \\
\hline & $\mathrm{p}$ & 0,000 & 0,000 & . & \\
\hline & $\mathrm{n}$ & 178 & 178 & 178 & \\
\hline \multirow[t]{2}{*}{ Maneviyat } & $\mathrm{r}$ & 0,480 & 0,106 & 0,461 & 1,000 \\
\hline & $\mathrm{p}$ & 0,000 & 0,080 & 0,000 & . \\
\hline
\end{tabular}




\begin{tabular}{|l|l|l|l|l|l|}
\hline & $\mathrm{n}$ & 178 & 178 & 178 & 178 \\
\hline
\end{tabular}

Yukarıdaki tabloda katılımcıların maneviyatları ile hadis ve sünnet algısı arasındaki ilişkiyi açıklayan spearman korelasyon analizi gösterilmektedir. Tablo incelendiğinde Maneviyatla hadis ve sünnet algısı bilgi alt boyutunda $r=0,480$ düzeyinde; hadis ve sünnet algısı toplam puanında ise $r=0,461$ düzeyinde pozitif yönlü korelasyon vardır. Bu sonuçla maneviyatın hadis ve sünnet algısı üzerinde anlamlı bir ilişki olduğunu, maneviyat düzeyi arttıkça hadis ve sünnet algısının da artacağı söylenebilir. Böylece "Öğrencilerin maneviyatları ile sünnet ve hadis algısı arasında anlamlı bir ilişki vardır." şeklindeki hipotezimiz doğrulanmıştır.

Maneviyatın hadis ve sünnet algısına etkisinin ne olduğunu belirlemek için basit doğrusal regresyon analizi aşağıdaki tabloda gösterilmektedir.

Tablo 19: Regresyon Tablosu

\begin{tabular}{|c|c|c|c|c|c|c|c|c|}
\hline $\begin{array}{l}\text { Bağımlı } \\
\text { Değişken }\end{array}$ & $\begin{array}{l}\text { Bağımsız } \\
\text { Değișken }\end{array}$ & B & $\mathbf{T}$ & p & $\mathbf{R}$ & $\mathbf{R}^{2}$ & $\mathbf{F}$ & $\mathbf{p}$ \\
\hline \multirow{2}{*}{$\begin{array}{l}\text { Hadis ve } \\
\text { Sünnet } \\
\text { Algısı }\end{array}$} & Sabit & 19,660 & 5,011 & 0,000 & \multirow{2}{*}{0,345} & \multirow{2}{*}{0,119} & \multirow{2}{*}{23,746} & \multirow{2}{*}{$0,000^{*}$} \\
\hline & Maneviyat & 0,177 & 4,873 & 0,000 & & & & \\
\hline
\end{tabular}

${ }^{*} \mathbf{p}<\mathbf{0 , 0 1}$

Regresyon tablosu incelendiğinde değişkenler arası ilişki düzeyi $\mathrm{R}=0,345$ olduğundan değişkenler arasında zayıf düzeyde pozitif korelasyon vardır. Determinasyon katsayısı ise $\mathrm{R}^{2}=0,119$ bulunmuştur. Bu sonuç bize Hadis ve sünnet algısındaki toplam değişimin \%11,9'unun katılımcıların maneviyatları tarafından belirlendiğini göstermektedir. Hadis ve sünnet algısındaki \%88,1'lik değişimin sebebi ise bilinmemektedir. F testinin significance (p) değeri 0,05 'ten küçük olduğundan $(0,000<0,05)$ regresyon modeli önemlidir. Dolayısıyla regresyon modeli tahmin için kullanılabilir. Yine yukarıdaki tabloda sabit değer 19,660 ve maneviyat parametresinin değeri de 0,117 olduğundan regresyon denklemi (Hadis ve sünnet algısı $=19,660+0,177^{*}$ Maneviyat) biçiminde yazılır. Sabit değerin pozitif olması maneviyat ile hadis ve sünnet algısı arasında doğru orantılı bir ilişki olduğunu, yani değişkenlerden birinin artması durumunda diğerinin de artacağını göstermektedir. Denklemde de görüleceği üzerine maneviyat puanındaki bir birim artış hadis ve sünnet algı düzeyinde 0,117 birim artıracaktır. Bu denklemi bir örnekle açılamak gerekirse maneviyat skoru 100 olan bir katılımcının hadis ve sünnet algısı skorunun ( HSÖ $=19,66+0,177^{*} 100$ ) denkleminden hareketle 37,36 olması beklenir.

\section{Sonuç}

$\mathrm{Bu}$ çalışma ilahiyat alanında niceliksel araştırma deseni ile yapılan nadir araştırmalardan biridir. Araştırma üniversite öğrencileri üzerinde gerçekleștirilmiş 
ve onların hadis ve sünnet algısına yönelik düşünceleri çeşitli değişkenler çerçevesinde araştırılmıştır. Araştırma meslek yüksekokulu öğrencilerinin sünnet ve hadis kavramları hakkında nasıl bir algıya sahip oldukları ve sünnet ve hadis kavramlarına ilişkin algı düzeylerinin kendi maneviyatlarıyla bir farklılık gösterip göstermediği sorularına cevap bulmak ve literatüre kaynak teşkil etmek için gerçekleştirilmiştir.

Öncelikle literatürde hadis ve sünnet algısına yönelik gerçekleştirilen bilimsel çalışmalara bakılmış fakat bireylerin hadis ve sünnet algısına yönelik bir ölçüm aracının geliştirilmediği görülmüştür. Bu sebeple araştırmamız bir boyut daha kazanarak ölçek geliştirmeye yönelik analizler yapılmış ve istatistiksel olarak öğrencilerin hadis ve sünnet algı düzeylerini ölçmeye yönelik Hadis ve Sünnet Algısı Ölçeği (HSÖ) geliştirilmiştir. Geliştirmiş olduğumuz ölçek ile daha önce Şirin tarafından geliştirilen Maneviyat Ölçeği araştırmamızın konusuna ve amacına yönelik istimal edilmiștir. Dolayısıyla öğrencilerin hadis ve sünnet algısı belirlenirken diğer taraftan da maneviyat düzeyleri belirlenmiş ve bu iki algı arasındaki ilişkiler de incelenmiştir. Bu çalışma daha önce de belirttiğimiz üzere bir ölçek geliştirme çalışması olmamakla birlikte ölçek geliştirmeye yönelik metotlar izlenerek standart bir ölçek geliştirilmiş ve aynı zamanda bu ölçek çalışmanın içerisinde kullanılarak hipotezler test edilmiştir.

Hadis ve Sünnet Algısı Ölçeği'ne (HSÖ) ilişkin sonuçlara bakıldığında Ölçek 10 madde ve iki alt boyuttan oluşmuştur. Ölçeğin KMO değeri =0,884 olarak hesaplanmış ve açımlayıcı faktör analizine tabi tutularak temel bileşenler analizi ve dik döndürme sonrası ölçek iki faktör altında toplanmış olup varyansın \%63,86'sını açıklamıştır. Ölçeğin Cronbach's Alfa ( $\alpha$ ) değeri 0,879 ve “Duygu ve Davranış Alt Boyutu” 0,893 ve "Bilgi Alt Boyutu" 0,659 olarak hesaplanmıştır. AFA sonrasında DFA uygulanmış ve uyum değerleri $[(\chi 2(934,406, \mathrm{sd}=45, \mathrm{p}=0.000) ; \chi 2 / \mathrm{sd}=2.612 ; \mathrm{RMSEA}=0.095$; $\mathrm{GFI}=0.912 ; \mathrm{AGFI}=0.858 ; \mathrm{CFI}=0.938 ; \mathrm{IFI}=0.939 ; \mathrm{NFI}=0.905 ; \mathrm{RFI}=0.874 ; \mathrm{RMR}=0,067$ ] şeklinde hesaplanmıştır (Tablo 1, 2, 3, 4). Bu sonuçlar geliştirilen ölçeğin öğrencilerin hadis ve sünnet algısını ölçmede kullanılabilecek güçlü bir ölçüm aracı olduğunu göstermekte ve bir bakıma bu araştırma ölçek geliştirme çalışmalarına benzer bir nitelik taşımaktadır.

Katılımcların dörtte üçünü kız öğrenciler oluşturmaktadır. Bu sonucun çıkmasında mevcut programların kız öğrenciler için daha çok tercih edilebilir

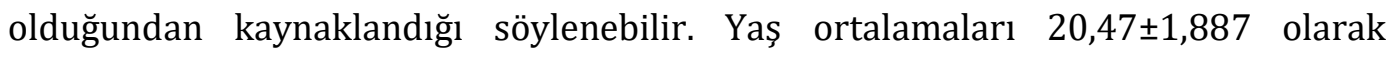
bulunmuştur. Öğrencilerin yarısına yakını Sosyal Hizmetler Bölümünde öğrenim görmekte, büyük bir çoğunluğu eğitim hayatında yurtta kalmaktadır (\%73). Katılımclarımızın anne eğitim durumlarına baktığımızda yarısından fazlası ilkokul mezunu iken babalarının da yarıya yakını (\%41) ilkokul mezunudur. Dolayısıyla katılımcılarımızın ebeveynlerinin eğitim düzeyi genel anlamda düşüktür diyebiliriz. Katılımcılarımızın daha önce mezun oldukları lise türüne baktığımızda yarısından biraz fazlası meslek lisesi mezunudur (AİHL veya Mesleki Teknik Lise). Öğrencilerin 
\%98,3'ünün hadis ve sünnet kavramlarının anlamını bildiği görülmüş, yarısına yakınının ise dini bilgilerini en çok aileden aldıkları görülmüştür. (Tablo 5).

Katılımcıların HSÖ puan ortalaması 38,59 $\pm 7,67$ 'dir. Ayrıca HSÖ'den alınan puanları 10 (düşük) < 23-36 (Orta) < 37 (Yüksek) şeklinde kategorize ederek değerlendirdiğimizde öğrencilerin \%5,6'sı düşük düzey, \%18,5'i orta düzey ve geriye kalan $\% 75,8$ 'i ise yüksek düzeyde hadis ve sünnet algısına sahip oldukları sonucuna ulaşılmıştır. Aynı zamanda katılımcı öğrencilerin maneviyat puanlarına baktığımızda $107,09 \pm 14,96$ olduğu sonucuna varılmıştır. Bu sonuçlar katılımcıların gerek hadis ve sünnet algısında gerekse de maneviyat algılarında oldukça yüksek algı düzeyine sahip olduklarını göstermektedir.

Öğrencilerin annelerinin eğitim düzeyi ile HSÖ ve Maneviyat puanlarının anlamlı bir şekilde farklılaşıp farklılaşmadığını belirlemek için oluşturulan hipotezimizi test etmek için yapılan analiz neticesinde HSÖ (Biliş Alt Boyutu)'nda $p=0,019$ ve HSÖ toplam ölçek puanında $p=0,045$ anlamlı farklılık bulgulanmış ve "H:6" hipotezimiz doğrulanmıştır. (Tablo 12)

Öğrencilerin lise türü değişkenine göre maneviyat, hadis ve sünnet algısı arasında anlamlı bir ilişki vardır şeklindeki hipotezimizi test etmek için yapılan analiz neticesinde HSÖ (Bilgi Alt Boyutu)'nda p=0,029 anlamlı farklılık bulgulanmış ve AİHL mezunlarının daha yüksek düzeyde hadis ve sünnet algısına sahip olduğu bulunmuştur. Bu sonuçla $\mathrm{H}: 10$ hipotezi kısmen doğrulanmıştır.

Katılımclarımızın dini bilgilerinin edinim şekli değişkenine göre maneviyat, hadis ve sünnet algısı arasında anlamlı farklılık olup olmadığını belirlemek için yapılan analiz neticesinde HSÖ (Duygu ve Davranış Alt Boyut)'nda p=0,030, HSÖ (Toplam) puanında $\mathrm{p}=0,017$ ve Maneviyat puanında $\mathrm{p}=0,019$ anlaml farklılık bulgulanmış olup H: 11 hipotezi doğrulanmıştır. Son olarak da katılımcıların maneviyatları ile hadis ve sünnet algıları arasında anlamlı bir ilişki vardır şeklindeki hipotezimiz korelasyon ve regresyon analizleriyle test edilmiş olup maneviyatla hadis ve sünnet algısı bilgi alt boyutunda $r=0,480$ düzeyinde; hadis ve sünnet algısı toplam puanında ise $r=0,461$ düzeyinde pozitif yönlü korelasyon tespit edilmiştir. Akabinde yapılan regresyon analizinde de maneviyat puanındaki bir birim artışın hadis ve sünnet algı düzeyinde 0,117 birim pozitif yönde artıracağı sonucu elde edilmiştir. $\mathrm{Bu}$ sonuçla H:12 hipotezimiz de doğrulanmıştır (Tablo 17,18,19). Diğer hipotezler ise doğrulanmamıştır.

Üniversite öğrencileri özelinde yapılan bu çalışmada ulaşılan sonuçların bir kısım sınırlılıkları vardır. Bu sınırlılıkları sıralamak gerekirse; araştırmanın gerçekleştiği zaman, mekân, örneklem kitlesi ve uygulanan araştırma yönteminin yanı sıra kullanılan ölçüm araçlarını söyleyebiliriz. Dolayısıyla ulaşılan sonuçlar bakımından bir genellemeye varmak doğru olmayacaktır. $\mathrm{Bu}$ sebepten bu araştırmaya benzer nitelikteki araştırmalara daha büyük örneklemler üzerinden, gerek niceliksel gerekse de niteliksel araştırmalar yapılması önerilmektedir. $\mathrm{Bu}$ araştırma neticesinde ulaşılan veriler özellikle İlahiyat alanında veya sosyal 
bilimlerde yapılacak araştırmalara kaynak teşkil edecektir. Ayrıca tarafımızca bu araştırma muhteviyatında geliştirilen HSÖ (Hadis ve Sünnet Algısı Ölçeği) daha büyük örneklemlerde ve çeşitli toplumsal grupların hadis ve sünnet algılarını ölçme amacıyla veya ölçek geliştirme çalışmalarında kullanılması önerilmektedir.

\section{Kaynakça}

Aytaç, Mustafa, Öngen, Burcu. "Doğrulayıcı Faktör Analizi İle Yeni Çevresel Paradigma Ölçeğinin Yapı Geçerliliğinin İncelenmesi". İstatistikçiler Dergisi: İstatistik ve Aktüerya 5 / 1 (Mart 2012), 14-22.

Büyüköztürk, Şener. Sosyal Bilimler İçin Veri Analizi El Kitabı. Ankara: Pegem Yayıncılık, 2002. Colye, Joanne. "Spirituality And Health: Towards a Framework for Exploring the Relationship Between Spirituality and Health" Journal of Advanced Nursing 37/6 (March 2002), 589-597.

Genç, Yusuf, Durğun, Arif. "Manevi Bakımın Gerekliliği ve Bakım Hizmeti Veren Meslek Elemanlarının Manevi Bakıma İlişkin Düşünceleri". Turkısh Studies Comperative $\begin{array}{llll}\text { Religious Studies } \quad 13 / 9 \quad \text { (Spring 2018), } & \text { 45-66. }\end{array}$ http://dx.doi.org/10.7827/TurkishStudies.13478

Genç, Yusuf, Durğun, Arif, Kara, Hüseyin Zahid, Çakır, Rahman. "İnternet Kullanımının Üniversite Öğrencilerinin Yalnızlık Algılarına Etkileri". Akademik İncelemeler Dergisi 13 / 2 (Ekim 2018), 301-336. https://doi.org/10.17550/akademikincelemeler.329440

Genç, Yusuf, Durğun, Arif. "Sağlık Çalışanlarının Dini Tutum Düzeyleri". Sakarya Üniversitesi Illahiyat Fakültesi Dergisi 20 / 38 (Aralı 2018), 253-281. https://doi.org/10.17335/sakaifd.430099

Hatiboğlu, İbrahim. "Sünnet ve Hadis (Seyyed Hossain Nasr)". Hadis Tetkikleri Dergisi 4 / 1 (Haziran 2006), 113-125.

Jung, Carl Gustav. Din ve Psikoloji. çev. Raziye Karabey. İstanbul: İnsan Yayınları, 3. Baskı, 2017. Kalaycı, Şeref vd. SPSS Uygulamalı Çok Değişkenli İstatistik Teknikleri. Ankara: Asil Yayın Dağıtım Ltd. Şti., 2006.

Kaptanoğlu Yıldırım, Ayșegül. Sağlık Alanında Hipotezden Teze: Veri Toplama ve Çözümleme Serüveni. İstanbul: Beşir Kitabevi, 2013.

Karagöz, Yalçın. SPSS-AMOS-META Uygulamalı İstatistiksel Analizler. Ankara: Nobel Akademik Yayıncllık, Güncellenmiş 2. Basım, 2019.

Kayri, Murat. "Araştırmalarda Gruplar Arası Farkın Belirlenmesine Yönelik Çoklu Karşllaștırma (Post-Hoc) Teknikleri”. Fırat Üniversitesi Sosyal Bilimler Dergisi 19/1 (Ocak 2009), 51-64.

Özdamar, Kazım. Eğitim, Sağlık ve Davranış Bilimlerinde Ölçek ve Test Geliştirme Yapısal Eşitlik Modellemesi IBM, SPSS, IBM SPSS AMOS ve MINITAB Uygulamalı. Eskișehir: Nisan Kitabevi, 2016.

Şirin, Turgay. “Maneviyat Ölçeği'nin Geliştirilmesi: Geçerlik ve Güvenirlik Çalışması. Turkısh Studies Social Sciences 13/18 (Summer 2018), 1283-1309. http://dx.doi.org/10.7827/TurkishStudies.13996

والحراك السنة / Tekin, Mustafa. "Sünnet ve Toplumsal Dinamikler / Sunnah and Social Dynamics الهجتمعي". Illahiyat Akademi / 7-8 (Aralık 2018), 163-174.

Ürkmez, Ahmed. "Sosyal Kesimler ve Sünnet Algıları Araştırması: Malatya (Hadis Alan Yorumu)". Süleyman Demirel Üniversitesi İlahiyat Fakültesi Dergisi / 28 (Haziran 2012), 97-128. 
Meslek Yüksekokulu Öğrencilerinin Hadis ve Sünnet Algısı | 647

Yeşil, Mahmut, Va'z Edebiyatında Hadisler. Ankara: TDV Yayınları, 1. Baskı, 2001.

Zencirkıran, Memet. Sosyoloji. Bursa: Dora Basım-Yayın Dağıtım, Yenilenmiș 7. Baskı, 2018. 
Ek:

HADİS VE SÜNNET ALGISI ÖLÇEĞİ (HSÖ)

\begin{tabular}{|c|c|c|c|c|c|c|}
\hline \multicolumn{2}{|r|}{$\begin{array}{l}\text { Bu ölçek meslek yüksekokulu öğrencilerinde "hadis ve } \\
\text { sünnet algısı" hakkındaki kanaatlerini tespit etmek } \\
\text { amacıyla hazırlanmıştır. Lütfen yan sütunda verilen } \\
\text { derecelendirmeyi kullanarak sizin görüşlerinize en } \\
\text { uygun olanı ve yalnızca her soru için bir tanesini "X" ile } \\
\text { işaretleyiniz ve kesinlikle boş bırakmayınız. Katılımınız } \\
\text { için teşekkür ederiz. }\end{array}$} & 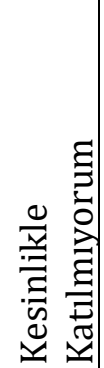 & 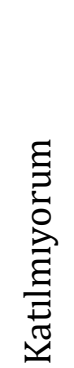 & 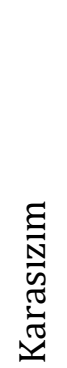 & 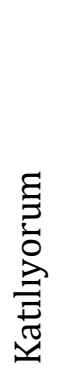 & 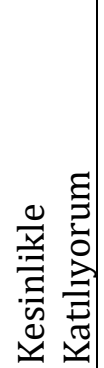 \\
\hline 1 & $\begin{array}{l}\text { Hz. Peygamber (sav) gibi yaşamak her } \\
\text { Müslüman'ın ideali olmalı. }\end{array}$ & & & & & \\
\hline 2 & $\begin{array}{l}\text { Çocuklarıma Hz. Peygamberin (sav) davranıș ve } \\
\text { düșüncelerini öğretmem gerektiğine inanıyorum. }\end{array}$ & & & & & \\
\hline 3 & $\begin{array}{l}\text { Hz. Peygamberin (sav) anlayışı ve davranışlarının } \\
\text { hayatıma yansımasını istiyorum. }\end{array}$ & & & & & \\
\hline 4 & $\begin{array}{l}\text { Dinin sünnete ve } \quad \text { Kuran'a } \quad \text { dayandığ } \\
\text { görüşündeyim. }\end{array}$ & & & & & \\
\hline 5 & $\begin{array}{l}\text { Ailemin Hz. Peygamberi (sav) tanımama katkısı } \\
\text { oldu. }\end{array}$ & & & & & \\
\hline 6 & Kuran'a inanmak sünnete bağlı kalmayı gerektirir. & & & & & \\
\hline 7 & Hz. Peygamberi (sav) anlatan kitapları okudum. & & & & & \\
\hline 8 & $\begin{array}{l}\text { “Hz. Peygamberin (sav) sünneti” denince aklıma ilk } \\
\text { önce sakal, sarık, tuzla yemeğe başlamak, oturarak } \\
\text { su içmek gibi şeyler geliyor. }\end{array}$ & & & & & \\
\hline 9 & $\begin{array}{l}\text { Hz. Peygamberin (sav) sünneti hakkındaki } \\
\text { bilgilerim yeterlidir. }\end{array}$ & & & & & \\
\hline 10 & Hayatıma yön veren hadisleri yeterince biliyorum. & & & & & \\
\hline
\end{tabular}

